Article

\title{
Impact of Chilling Rate on the Evolution of Volatile and Non-Volatile Compounds in Raw Lamb Meat during Refrigeration
}

\author{
Can Xiang, Shaobo Li, Huan Liu, Ce Liang, Fei Fang, Dequan Zhang $\mathbb{D}^{\mathbb{D}}$ and Zhenyu Wang * \\ Key Laboratory of Agro-Products Processing, Institute of Food Science and Technology, \\ Chinese Academy of Agricultural Sciences, Ministry of Agriculture and Rural Affairs, Beijing 100193, China; \\ xiangcan97@126.com (C.X.); lishaobo@caas.cn (S.L.); sd_lh1990@126.com (H.L.); celiang312@163.com (C.L.); \\ fangfei@caas.cn (F.F.); dequan_zhang0118@126.com (D.Z.) \\ * Correspondence: caasjgsmeat2021_1@126.com; Tel./Fax: +86-10-6281-8740
}

Citation: Xiang, C.; Li, S.; Liu, H.; Liang, C.; Fang, F.; Zhang, D.; Wang, Z. Impact of Chilling Rate on the

Evolution of Volatile and Non-Volatile Compounds in Raw Lamb Meat during Refrigeration. Foods 2021, 10, 2792. https:// doi.org/10.3390/foods10112792

Academic Editor: Andrea Garmyn

Received: 26 September 2021 Accepted: 4 November 2021 Published: 12 November 2021

Publisher's Note: MDPI stays neutral with regard to jurisdictional claims in published maps and institutional affiliations.

Copyright: (c) 2021 by the authors. Licensee MDPI, Basel, Switzerland. This article is an open access article distributed under the terms and conditions of the Creative Commons Attribution (CC BY) license (https:// creativecommons.org/licenses/by/ $4.0 /)$.
Abstract: The aim of this study was to investigate the effect of chilling rate $\left(1.44,22.2\right.$, and $\left.32.4{ }^{\circ} \mathrm{C} / \mathrm{h}\right)$ on the evolution of volatile and non-volatile compounds in raw lamb meat during refrigeration $(1,24,72$, and $120 \mathrm{~h})$. Through orthogonal projection to latent structure-discriminant analysis, the calculation of odor activity values (OAV > 1) and taste activity values (TAV > 1) analysis, 1-octen-3-ol, (E, E)-2,4-decadienal, nonanal, hexanal, nona-3,5-dien-2-one, 2,3-octanedione, hexanoic acid, 1-nonen4-ol, aspartate (Asp), Glutamic Acid (Glu), 5'-GMP, 5'-IMP, and 5'-AMP were regarded as differential flavor or taste compounds for raw meat undergone different chilling rates. With a rapid chilling rate at $24 \mathrm{~h}$ after slaughter, the contribution of 1-octen-3-ol decreased, but (E, E)-2,4-decadienal increased. Moreover, at $24 \mathrm{~h}$ post-mortem, the equivalent umami concentration of Asp, Glu, $5^{\prime}-\mathrm{GMP}, 5^{\prime}$-IMP and $5^{\prime}$-AMP in raw meat were significantly lower at a chilling rate of $1.44{ }^{\circ} \mathrm{C} / \mathrm{h}$ than $32.4^{\circ} \mathrm{C} / \mathrm{h}(p<0.05)$. Conclusively, under the rapid chilling rate, more fatty odor and umami compounds accumulated in $24 \mathrm{~h}$ aged meat.

Keywords: chilling rate; refrigeration; volatile and non-volatile compound; raw lamb meat

\section{Introduction}

Flavor is one of the dominant factors determining the quality of meat and consumer purchasing decisions [1]. Although the flavor of raw meat is slight, it is also an indicator for consumers to evaluate meat freshness and nutrition-related attributes [2]. Meanwhile, some volatile and non-volatile precursors are always produced during refrigeration of raw meat and will determine the cooking quality and sensory attributes of meat products [3]. Therefore, the control and improvement of the volatile and non-volatile compounds in raw meat is a hot topic globally. Many factors influence the volatile and non-volatile compounds in raw meat, such as breeds, gender, age, slaughtering methods, aging time, packaging methods, and storage conditions [4]. Aging after $4{ }^{\circ} \mathrm{C}$ chilling is the most popular way to preserve freshness and tenderization of raw meat. Some recent studies reported that compared with traditional $4{ }^{\circ} \mathrm{C}$ chilling, fast chilling sped up the reduction of carcass's temperature and reduced purge losses and cooking losses $[5,6]$. Rapid chilling of pre-rigor carcasses significantly slowed the post-mortem process [7], reduced the rate of $\mathrm{pH}$ decline, and inhibited glycolysis [8,9]. Meanwhile, chilling method affected the degree of lipid oxidation and protein degradation, to produce different volatile and nonvolatile compounds such as free fatty acid, oxidative free radical, peptides, and amino acids, which would contribute to cooked meat aroma [1]. Therefore, several researchers raised the possibility that changing the rate of carcass chilling after slaughter may affect meat volatile and non-volatile compounds $[10,11]$. However, studies only showed that accelerated chilling can improve the physical and chemical properties of meat due to the 
reduced post-mortem metabolic rate [7,12], the volatile and non-volatile compounds in raw meat cut from the chilled carcass with different chilling rates during refrigeration were not well understood.

The aims of this study were to (1) classify raw meat at different chilling rates and refrigeration times based on analysis of volatile and non-volatile compounds; (2) identify the key and differential volatile and non-volatile compounds in response to different chilling rates, and (3) investigate the evolution of key volatile and non-volatile compounds at different chilling rates during refrigeration.

\section{Materials and Methods}

\subsection{Sample Preparation}

Eighteen 6-month-old Small-Tail sheep ( $24.27 \pm 0.73 \mathrm{~kg}$ carcass weight) were randomly obtained from six sheep pens (each pen for three sheep), in Mongolia Grassland Hongbao Food Co., Ltd. (Bayannur, Inner Mongolia, China). All sheep had similar genetic backgrounds and diets. Sheep were slaughtered in accordance with the principles and guidelines established by the Committee for the use of the Institute of Food Science and Technology of the Chinese Academy of Agricultural Sciences. Every three sheep from the same pen were randomly divided into 3 groups (G1, G2, and G3, respectively), resulting in 6 sheep per group. According to the technical specifications for cutting lamb (NY/T 15642007) (The Ministry of Agriculture and Rural Affairs of the People's Republic of China, 2007), similar to backstrap 5101 in the seventh edition of the Australian Meat Manual (Australia, 2005) [13], the left longissimus dorsi was removed and trimmed within $30 \mathrm{~min}$ after slaughter. No external fat remained on the longissimus muscle, and the silverskin was removed. Longissimus dorsi muscles were portioned into 4 equally sized segments and allocated to refrigeration of $1,24,72$, and $120 \mathrm{~h}$ from the time of bloodletting, and their initial temperatures were recorded (the thermometer probe was inserted at a depth of about $2 \mathrm{~cm}$ ). The samples were transferred to chilling rooms within 45 min postmortem, and the thermometer parameters were set to automatically record data every $10 \mathrm{~min}$. G1 samples were chilled at $4{ }^{\circ} \mathrm{C}$, the final temperature was $4{ }^{\circ} \mathrm{C}$, while the rate of chilling was $1.44^{\circ} \mathrm{C} / \mathrm{h}$. G2 samples were chilled at $-20^{\circ} \mathrm{C}$ until the central temperature dropped to $-1{ }^{\circ} \mathrm{C}$, and the chilling rate was $22.2^{\circ} \mathrm{C} / \mathrm{h}$. G3 samples were chilled at $-35^{\circ} \mathrm{C}$, the final temperature was $-1{ }^{\circ} \mathrm{C}$, while the rate was $32.4^{\circ} \mathrm{C} / \mathrm{h}$. Then the samples were transferred to refrigerate at $4{ }^{\circ} \mathrm{C}$. The samples of the three groups were collected at $1,24,72$, and $120 \mathrm{~h}$ postmortem, dissected into small pieces, snap-frozen in liquid nitrogen, and stored at $-80{ }^{\circ} \mathrm{C}$ until analysis.

\subsection{Electronic Nose Analysis}

The PEN 3.5 (Airsense Analytics GmbH, Schwerin, Germany) system consists of a sampling unit, a sensor chamber containing an array of 10 metal oxide semiconductor type chemical sensors, and pattern recognition software (Winmuster) for data recording and analysis. The Sensors include W1C (sensitive to aromatic components, benzene), W3C (sensitive to aromas, ammonia), W5C (sensitive to short-chain alkane aromatic components), W1S (sensitive to methyl compounds), W2S (sensitive to alcohols, aldehydes, and ketones), W3S (sensitive to long-chain alkanes), W5S (sensitive to nitrogen oxides), W6S (sensitive to hydrides), W1W (sensitive to sulphides) and W2W (sensitive to organic sulphides). PEN 3.5 portable electronic nose was used to obtain the response values of samples [14]. Two grams of minced sample were placed in a $20 \mathrm{~mL}$ headspace vial for $30 \mathrm{~min}$ at $25 \pm 1{ }^{\circ} \mathrm{C}$ to generate enough volatile compounds. Samples were tested by headspace sampling, and the sample gas was injected into the sensor chamber at a flow rate of $300 \mathrm{~mL} / \mathrm{min}$ for $60 \mathrm{~s}$. The response values of each sensor with a detection time of 56-58 s were recorded. The cleaning stage of the electronic nose was conducted to balance sensor signals by indrawing clean air into the sample gas path for $180 \mathrm{~s}$. 


\subsection{Electronic Tongue Analysis}

E-tongue ( $\alpha$-Astree; Alpha MOS Company, Toulouse, France) was used to acquire the taste signals of raw meat, including seven liquid cross-sensitive sensors which were AHS (detect sour compounds), ANS (detect sweet compounds), SCS (detect bitter compounds), CTS (detect salty compounds), NMS (detect umami compounds), PKS and CPS (detect compound compounds). Four grams of minced sample were immersed in $20 \mathrm{~mL}$ ultra-pure water and homogenized for $1.5 \mathrm{~min}$, then the volume was fixed to $120 \mathrm{~mL}$, ultrasonic extraction for $20 \mathrm{~min}$ to extract compounds completely. To protect the sensors, samples need to centrifuge for $15 \mathrm{~min}\left(4^{\circ} \mathrm{C}, 10,000 \mathrm{r} / \mathrm{min}\right)$ and filtered by $0.45 \mu \mathrm{m}$ membrane, and then $100 \mathrm{~mL}$ samples were poured into a $120 \mathrm{~mL}$ beaker for detection. The detection time was set to 2 min to ensure that the sensor obtains sufficient taste information for each sample. The sensors were flushed in ultrapure water for $10 \mathrm{~s}$ to reach a stable state. The process was repeated seven times for each sample.

\subsection{Volatile Compounds Analysis}

2.4.1. Headspace Solid-Phase Microextraction/Gas Chromatography-Mass Spectrometry (HS-SPME/GC-MS) Analysis

The volatile compounds in raw meat were tested as described by Liu et al. [15] with minor modifications. The volatile compounds were extracted by headspace solidphase microextraction (HS-SPME). Three grams chopped sample and $1.5 \mu \mathrm{L}$ 2-methyl3-heptanone solution $(1.60 \mu \mathrm{g} / \mathrm{mL}$ in methanol) as an internal standard were placed in a $20 \mathrm{~mL}$ headspace vial. The vials were kept incubated at $50^{\circ} \mathrm{C}$ for $20 \mathrm{~min}$. The $65 \mu \mathrm{m}$ polydimethylsiloxane/divinylbenzene fused silica (PDMS/DVB) coating fiber (Supelco, Inc., Bellefonte, PA, USA) was exposed to the headspace vial for $40 \mathrm{~min}$ to absorb the volatile compounds. The fiber was inserted into the sampler of a gas chromatograph (GC) for $2 \mathrm{~min}$ for desorption. A gas chromatograph-mass spectrometer (GC-MS) (QP2010plus, Shimadzu) equipped with a DB-WAX $(30 \mathrm{~m} \times 0.25 \mathrm{~mm} \times 0.25 \mu \mathrm{m})$ was used to detect volatile compounds in raw meat. Helium has a flow rate of $1 \mathrm{~mL} / \mathrm{min}$ as a carrier. The temperatures of the injector and ion source were $200{ }^{\circ} \mathrm{C}$, and $250{ }^{\circ} \mathrm{C}$, respectively. The initial temperature of the oven was $40^{\circ} \mathrm{C}$, and the heating procedure of the oven was held at $40{ }^{\circ} \mathrm{C}$ for $3 \mathrm{~min}$, ramped up to $120^{\circ} \mathrm{C}$ at $5^{\circ} \mathrm{C} / \mathrm{min}$, ramped up to $200{ }^{\circ} \mathrm{C}$ at $10^{\circ} \mathrm{C} / \mathrm{min}$, and held for $13 \mathrm{~min}$. Mass spectrometry was performed in electron collision mode (EI) with a voltage of $70 \mathrm{eV}$ and a full scan mode of $35-500 \mathrm{~m} / z$.

According to the computer spectrum library (NIST11, NIST11s), compounds with the matching degree of volatile compounds greater than 80 were identified by MS, and the highest matching degree was 100. LRIs were analyzed according to the retention times of external standard n-alkanes $\left(\mathrm{C}_{7}-\mathrm{C}_{40}\right)$ under the same GC-MS-detection conditions, and LRIs were compared with n-alkanes $\left(C_{7}-C_{40}\right)$ reported in the literature to identify the aromatic compounds [16]. Semi-quantitative analysis of volatile compounds in raw meat was carried out using 2-methyl-3-heptanone as an internal standard. The concentration of volatile compounds was calculated according to the peak area ratio and the concentration of 2-methyl-3-heptanone.

\subsubsection{Calculations of Odor Activity Values (OAVs)}

To evaluate the contribution of volatile compounds to raw meat, odor activity value $(\mathrm{OAV})$ and contribution rate were calculated. The ratio of concentration to perceptual threshold presented OAV [17], the ratio of the OAV to the total OAVs represented the contribution rate of these compounds. Compounds with OAV greater than 1 may be the main contributors, while compounds with OAV less than 1 may be the secondary contributors.

\subsection{Free Amino Acids Analysis}

The contents of free amino acids (FAAs) of raw meat were measured as described by Zhang et al. $[15,18]$ with some modifications. The FAAs contents in the samples were detected by using L8900 Amino Acid Analyzer (Hitachi High-Technologies Corporation, 
Tokyo, Japan). Two grams of minced meat were added with $15 \mathrm{~mL} \mathrm{HCl}(0.1 \mathrm{~mol} / \mathrm{L})$. The mixture was homogenized for $2 \mathrm{~min}$ and centrifuged $\left(8500 \mathrm{r} / \mathrm{min}, 4^{\circ} \mathrm{C}\right)$ for $15 \mathrm{~min}$. One milliliter of supernatant was added to $1 \mathrm{~mL}$ of sulfosalicylic acid ( $8 \%$ ) and centrifuged again $\left(10,000 \mathrm{r} / \mathrm{min}, 15 \mathrm{~min}, 4^{\circ} \mathrm{C}\right)$. Then, $1 \mathrm{~mL}$ of supernatant was dried under nitrogen $\left(40^{\circ} \mathrm{C}\right)$ and dissolved in $1 \mathrm{~mL}$ of hydrochloric acid solution $(0.02 \mathrm{~mol} / \mathrm{L})$. The filtration solution was tested after filtration through a pinhole filtration membrane $(0.22 \mu \mathrm{m})$.

\subsection{Nucleotide Analysis}

The contents of nucleotides in raw meat were detected by using high-performance liquid chromatography (HPLC) equipped with a TSK gel ODS-80TM $(4.6 \mathrm{~mm} \times 250 \mathrm{~mm}$ $\times 5 \mu \mathrm{m})$ (Tosoh quartz Co., Ltd., Tainan, Japan) [15,19]. Ten grams of minced meat were added with $30 \mathrm{~mL} \mathrm{HClO}_{4}(5 \%)$. The mixture was homogenized $(10,000 \mathrm{r} / \mathrm{min}, 2 \times 20 \mathrm{~s})$ and centrifuged $\left(8500 \mathrm{r} / \mathrm{min}, 4^{\circ} \mathrm{C}\right)$ for $10 \mathrm{~min}$, and the supernatant was filtered through a medium speed filter paper. After that, the $\mathrm{pH}$ of the filtrate was adjusted to 5.4, and the volume was adjusted to $100 \mathrm{~mL}$. The filtrates were tested after filtration through a pinhole filtration membrane $(0.22 \mu \mathrm{m})$.

The column and UV wavelengths of HPLC were $30^{\circ} \mathrm{C}$ and $254 \mathrm{~nm}$, respectively. The injection volume was $10 \mu \mathrm{L}$, and the rate of flow was $0.6 \mathrm{~mL} / \mathrm{min}$. The mobile phase solvents were methanol (A) and $0.05 \mathrm{~mol} / \mathrm{L}$ potassium dihydrogen phosphate buffer solution $(\mathrm{pH}=5.4)(\mathrm{B})$. The gradient elution was carried out with binary mobile solvents, in which the ratio of methanol to $0.05 \mathrm{~mol} / \mathrm{L}$ potassium dihydrogen phosphate was as follows: 0-10 $\mathrm{min}: 0 \% / 100 \%, 11-17 \mathrm{~min}: 10 \% / 90 \%, 18-25 \mathrm{~min}: 0 \% / 100 \%$, the detection lasted for $25 \mathrm{~min}$.

\subsection{Calculations of Equivalent Umami Concentrations (EUCs) and Taste Active Values (TAVs)}

The EUCs of taste compounds were calculated as follows:

$$
\mathrm{Y}=\Sigma \mathrm{a}_{\mathrm{i}} \mathrm{b}_{\mathrm{i}}+1218\left(\sum \mathrm{a}_{\mathrm{i}} \mathrm{b}_{\mathrm{i}}\right) \sum \mathrm{a}_{\mathrm{j}} \mathrm{b}_{\mathrm{j}}
$$

Y was the EUC of the raw meat (g MSG/100 g). ai and aj were the concentrations of umami amino acids (Glu or Asp) (g/100 g) and taste nucleotides (5'-AMP, 5'-IMP, 5'-GMP) ( $\mathrm{g} / 100 \mathrm{~g})$, respectively. bi and $\mathrm{bj}$ were the relative umami coefficients of the umami amino acids to MSG (Glu: 1; Asp: 0.077) and the relative umami coefficients of taste nucleotides to IMP (5'-AMP: 0.18; 5'IMP: 1; 5'-GMP: 2.3), respectively.

The TAVs of the taste compounds in raw meat were calculated as the ratio of the concentration of each compound to the taste threshold. A TAV greater than 1 indicated that the compound made a significant contribution to the taste of the sample. Conversely, it had a secondary impact on the taste.

\subsection{Statistical Analysis}

All statistical analyses of volatile and non-volatile compounds of raw meat were conducted using SPSS 26.0 software (IBM Corporation, Armonk, NY, USA). Data were compared between groups using a general linear model analysis of variance. Duncan's multiple range test was applied to analyze differences $(p<0.05)$. Orthogonal projection to latent structure-discriminant analysis (OPLS-DA) was fulfilled by SIMCA 14.1 (MKS Data Analytics Solutions, Umea, Sweden). Results were expressed as the means \pm standard deviation $(n=6)$.

\section{Results and Discussion}

3.1. Volatile and Non-Volatile Compounds Identification of Raw Meat with Different Chilling Rates and Different Refrigeration Times

\subsubsection{Effect of Chilaling Rates}

The OPLS-DA model was used as an internal prediction validation method in which $\mathrm{Q}^{2}$ represented the degree of prediction of the model, $\mathrm{R}^{2} \mathrm{X}$ on the $X$-axis represented the model's goodness of fit (GOF), and $\mathrm{R}^{2} \mathrm{Y}$ on the $Y$-axis represented the GOF of the model. 
The OPLS-DA results for the classification of volatile and non-volatile compounds in raw meat at different chilling rates were shown in Figure 1. For the identification of volatile compounds at different chilling rates (Figure $1 \mathrm{a}$ ), the values of $R^{2} X, R^{2} Y$, and $Q^{2}$ were 0.846 , 0.65 , and 0.543 , respectively. Correspondingly, for the non-volatile compounds at different chilling rates (Figure $1 b$ ), the values of $R^{2} X, R^{2} Y$, and $Q^{2}$ were $0.981,0.264$, and 0.211, respectively. The non-volatile compounds of samples with chilling rates of $1.44,22.2$, and $32.4^{\circ} \mathrm{C} / \mathrm{h}$ partially clustered together, indicating similarities within the samples that made separation difficult, while for the volatile compounds of samples with chilling rates of 1.44, 22.2 , and $32.4^{\circ} \mathrm{C} / \mathrm{h}$ were separated completely. Regarding the volatile compounds, in the scoring plots of samples with chilling rates of $1.44,22.2$, and $32.4{ }^{\circ} \mathrm{C} / \mathrm{h}$, good inter-class variation could be observed along the first predicted component (Figure 1a). Meanwhile, negative scores correspond to samples with a chilling rate of $32.4^{\circ} \mathrm{C} / \mathrm{h}$ and positive scores of $22.2{ }^{\circ} \mathrm{C} / \mathrm{h}$. Samples with a chilling rate of $1.44{ }^{\circ} \mathrm{C} / \mathrm{h}$ had a positive distribution on $\mathrm{t}[2]$. Correspondingly, the score plot for non-volatile compounds (Figure $1 \mathrm{~b}$ ) showed a grouping of samples with a chilling rate of $32.4^{\circ} \mathrm{C} / \mathrm{h}$ distributed prevalently as negative scores on $\mathrm{t}[2]$, while the best separation between 1.44 and $22.2^{\circ} \mathrm{C} / \mathrm{h}$ samples was provided by $\mathrm{t}[1]$.

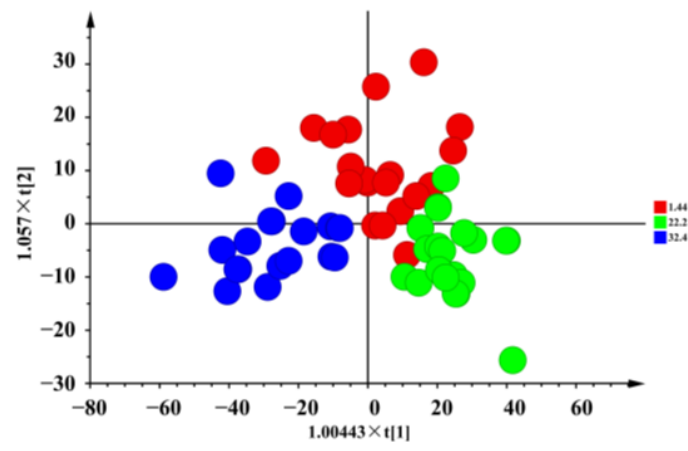

(a)

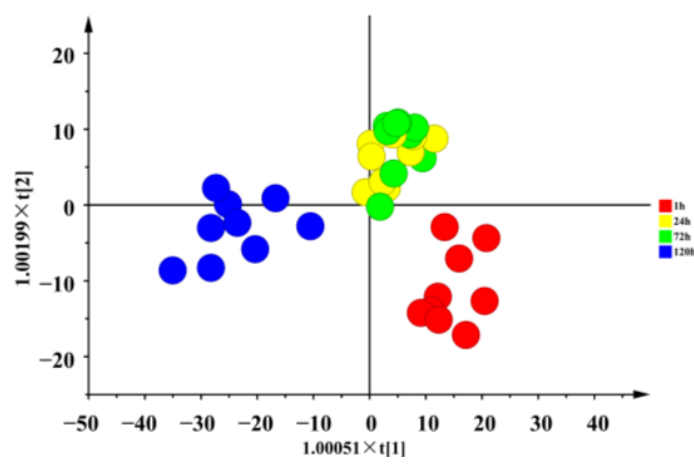

(c)

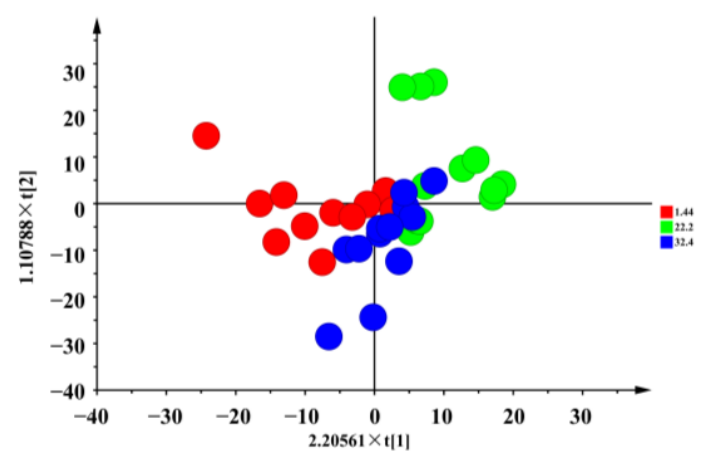

(b)

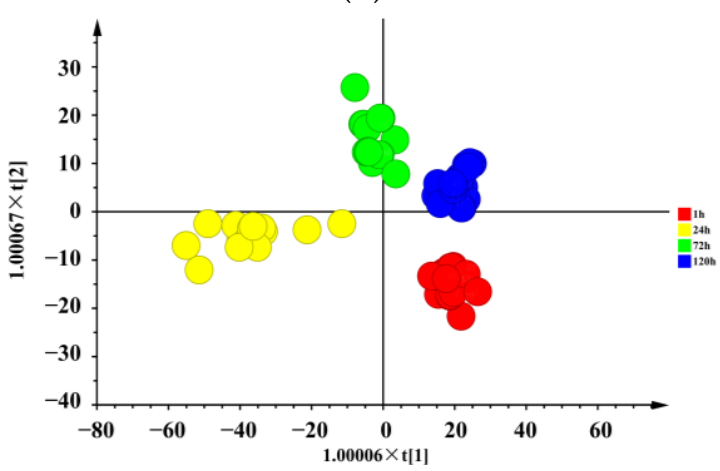

(d)

Figure 1. OPLS-DA score plots of volatile compounds and non-volatile compounds in raw meat at different chilling rates and different refrigeration times. (a) OPLS-DA score plot of volatile compounds at different chilling rates. (b) OPLS-DA score plot of non-volatile compounds at different chilling rates. (c) OPLS-DA score plot of volatile compounds at different refrigeration times. (d) OPLS-DA score plot of non-volatile compounds at different refrigeration times.

The result showed that increasing the chilling rate altered the volatile and non-volatile compounds of raw meat, especially the volatile compounds. Previous studies reported that a rapid chilling rate could reduce the rate of $\mathrm{pH}$ decline [20], which affected the glycolysis and enzymatic activities [21-23]. Furtherly, the rapid chilling could affect the concentration of volatile and non-volatile precursors [24,25], resulting in different flavors of raw meat at different chilling rates. Also, protein oxidation and lipid oxidation have a great influence on the flavor and consumer acceptance of raw meat [26]. Storing meat at lower temperatures slowed down the oxidation and spoilage process $[27,28]$, which remained and even improved raw meat flavor. 


\subsubsection{Effect of Refrigeration Times}

For the classification of volatile compounds in raw meat with different refrigeration times (Figure 1c), the values of $R^{2} X, R^{2} Y$, and $Q^{2}$ were $0.969,0.924$, and 0.852 , respectively. Correspondingly, for non-volatile compounds in raw meat with different refrigeration times (Figure $1 d$ ), the values of $R^{2} X, R^{2} Y$, and $Q^{2}$ were $0.917,0.851$, and 0.605 , respectively. Four distinct clusters were also identified along the two first predictive components, $\mathrm{t}[1]$ and $\mathrm{t}[2]$, of the score plot for volatile compounds modeled according to refrigeration times (Figure 1c). 24, 72, and $120 \mathrm{~h}$ subjects were well discriminated along the $\mathrm{t}[1]$. Variability between 1 and $120 \mathrm{~h}$ subjects was collected by $\mathrm{t}$ [2]. In the score plot of the non-volatile compounds calibration model (Figure 1d), excellent inter-class comparability between the 1 and $120 \mathrm{~h}$ samples could be observed for the first predictive component, where negative scores correspond to $120 \mathrm{~h}$ samples and positive scores to $1 \mathrm{~h}$ samples. Score plot for the non-volatile compounds also showed a grouping of $24 \mathrm{~h}$ and $72 \mathrm{~h}$ samples that distributed prevalently as positive scores on the $t[2]$.

The transformation of muscle into meat after slaughter is accompanied by many biochemical and structural activities. These processes have been shown to be influenced by post-slaughter handling $[29,30]$ and to affect the volatile and non-volatile compounds, tenderness, color, and other qualities of the raw meat [31]. The conduction of volatile and non-volatile compounds at different times after slaughter were affected by protein oxidation and lipid oxidation [32]. The formation of post-mortem peptides, free fatty acids, and oxidative free radicals led to the generation of flavor precursors, which in turn produced different volatile and non-volatile compounds [1,33].

\subsection{Identification of Key Volatile and Non-Volatile Compounds in Raw Meat during Refrigeration}

3.2.1. Key Volatile and Non-Volatile Compounds

Volatile compounds with odor-activity values $(\mathrm{OAVs})>1$ made a dominant contribution to raw meat, while compounds with $\mathrm{OAVs}<1$ contributed less [16]. The concentration of a volatile compound was divided by the published odor threshold in water to determine its OAV. As shown in Figure 2a, 16 volatile compounds with OAVs $>1$ were set out below: nonanal, octanal, decanal, (E)-4-decenal, (E)-2-nonanal, (E)-2-octenal, $(\mathrm{E}$, E)-2,4-decadienal, (E, E)-2,4-nonadienal, heptanol, heptanal, 1-octen-3-ol, (E)-2-octen-1-ol, hexanoic acid, 2-pentylfuran, 2,3-octanedione, and methyl hexanoate. To intuitively explain the contribution of volatile compounds to raw meat, the contribution rate was used to elaborate. As shown in Figure $3 b$, the higher contribution rates of volatile compounds in raw meat were 1-octen-3-ol (19.31-56.21\%), (E, E)-2,4-decadienal (10.7-25.34\%), and nonanal $(9.50-20.34 \%)$, and they accounted for almost $80 \%$ of the contribution rates. 1-octen-3-ol, (E, E)-2,4-decadienal, and nonanal could be recognized as key volatile compounds in raw meat during refrigeration. Consistently, several studies demonstrated that nonanal, (E, E)-2,4-decadienal, and 1-octen-3-ol had higher OAVs in raw and cooked meat [15,34,35]. Alcohols were typical volatile markers of raw and unprocessed meat. They were mainly oxidative decomposition products of fat, especially 1-octen-3-ol, which had a mushroom odor and was reported to be generated by $\beta$-oxidation [36-38]. The aldehydes with the largest contribution rate of volatile compounds were (E, E)-2, 4-decadienal, and nonanal, which had the odor of fat $[17,39]$.

Taste activity values (TAVs) identified the main non-volatile compounds. As shown in Figure 2b, aspartic acid (Asp), Glu, $5^{\prime}$-GMP, $5^{\prime}$-IMP, and $5^{\prime}$-AMP had a TAV greater than 1 . Therefore, they were key non-volatile compounds in raw meat. Glu, $5^{\prime}$-GMP and $5^{\prime}$-IMP were widely regarded as monosodium glutamate (MSG)-like components that gave a pleasant broth or a rich meaty odor $[39,40]$. Previous studies showed that nucleotides, such as $5^{\prime}$-GMP, $5^{\prime}$-IMP, and $5^{\prime}$-AMP, usually be added to raw meat in order to improve the sweetness and umami taste, while some free amino acids such as Asp and Glu were also umami-taste-related free amino acids [41-43]. In addition, nucleotides, and umami amino acids (UAA) created synergies to enhance the taste of meat. In agreement with previous studies [44], MSG-like components were the key non-volatile components in raw meat. 


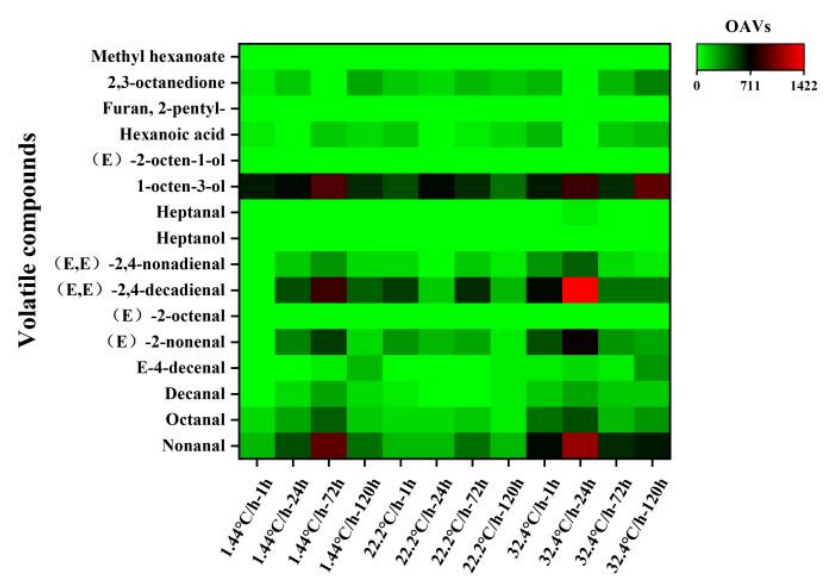

(a)

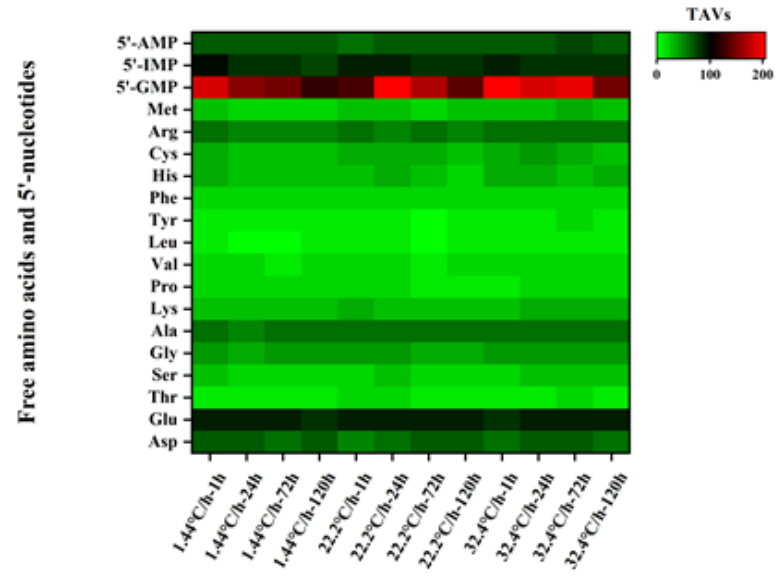

(b)

Figure 2. OAVs and TAVs of volatile compounds and non-volatile compounds in raw meat at different chilling rates during refrigeration. (a) OAVs of volatile compounds. (b) TAVs of non-volatile compounds.

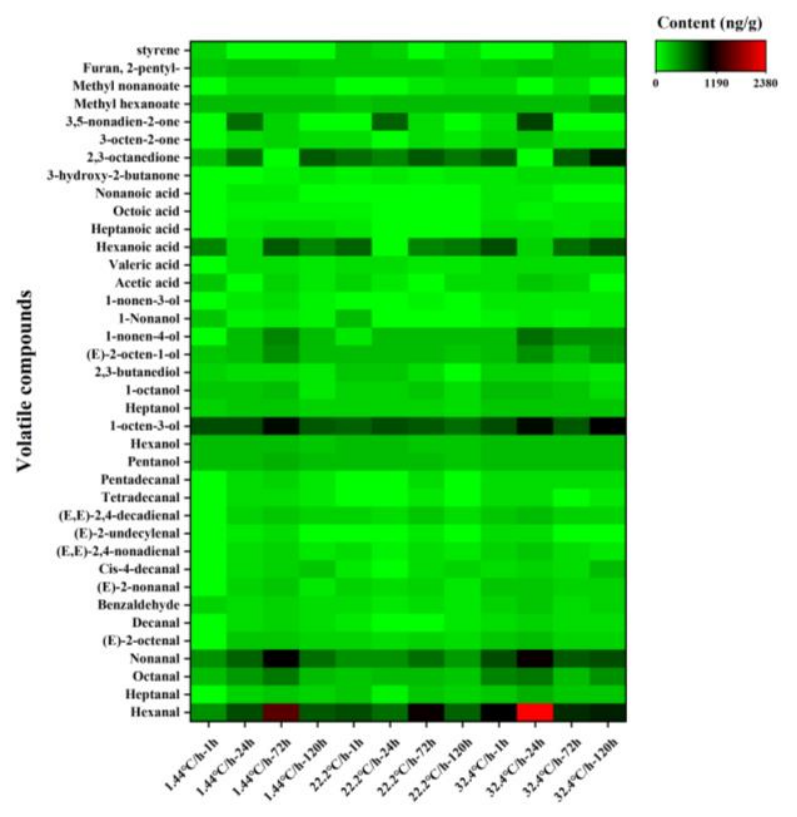

(a)

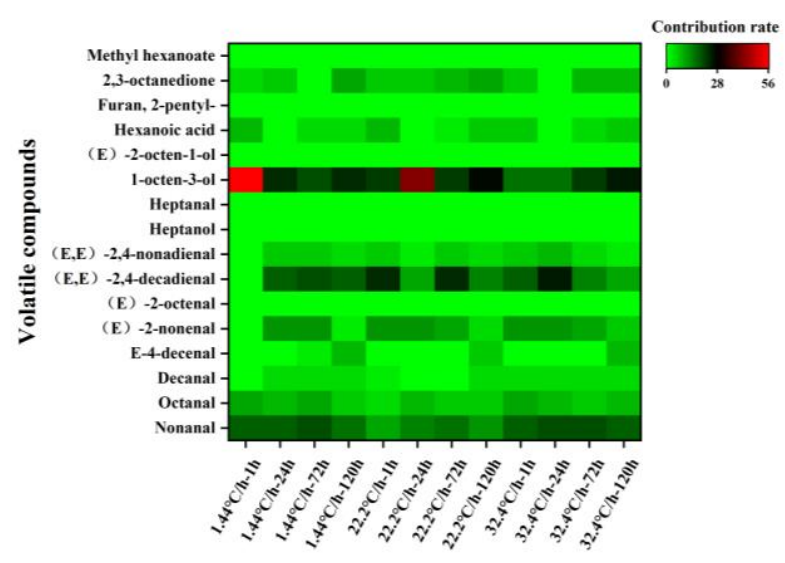

(b)

Figure 3. Contents and Contribution rates of volatile compounds in raw meat at different chilling rates during refrigeration. (a) Contents of volatile compounds. (b) Contribution rates of volatile compounds.

\subsubsection{Differential Metabolites in Raw Meat: Effect of Chilling Rates}

Six variables were regarded as critical volatile compounds in raw meat at different chilling rates, as their variable importance in projection (VIP) were all above 1.5 (Figure 4a). The name and VIP values of these six compounds were: hexanal (3.14), 2,3-octanedione (2.49), nonanal (2.65), 1-octen-3-ol (2.24), hexanoic acid (1.92), octanal (1.58). According to Figure $4 \mathrm{~b}$, among the non-volatile compounds, $5^{\prime}$-inosinic acid (IMP) and $5^{\prime}$-guanylic acid (GMP) were differential compounds at different chilling rates, and the VIP values were 4.85 and 1.81, respectively. Therefore, hexanal, 2,3-octanedione, nonanal, 1-octen-3-ol, hexanoic acid, octanal, 5'-IMP, and 5'-GMP were the critical volatile metabolites in raw meat at different chilling rates. 


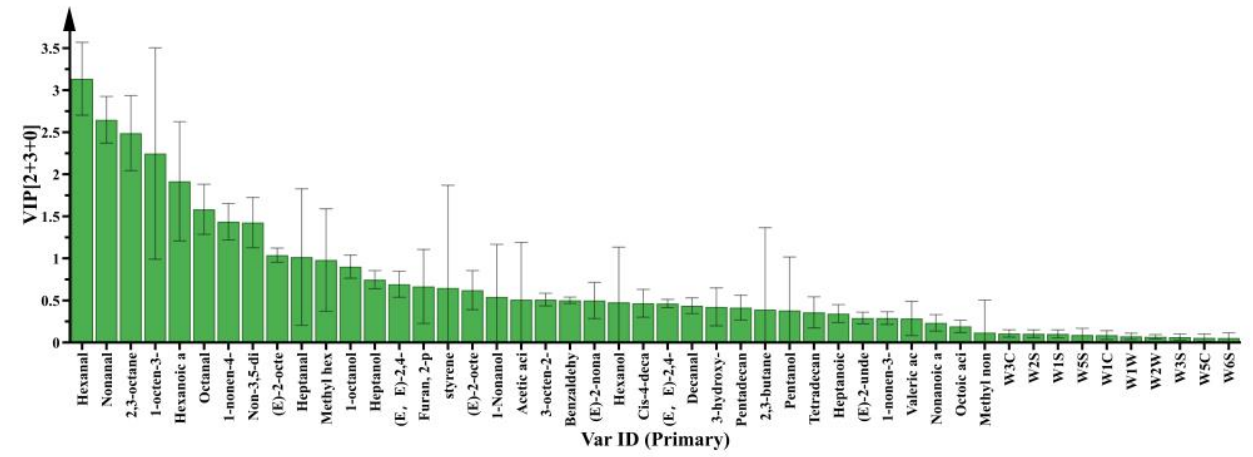

(a)

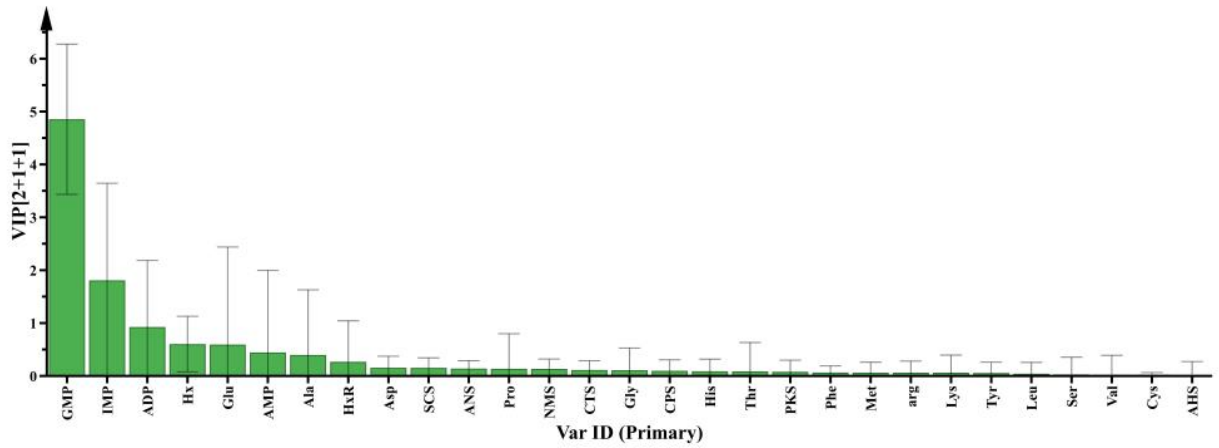

(b)

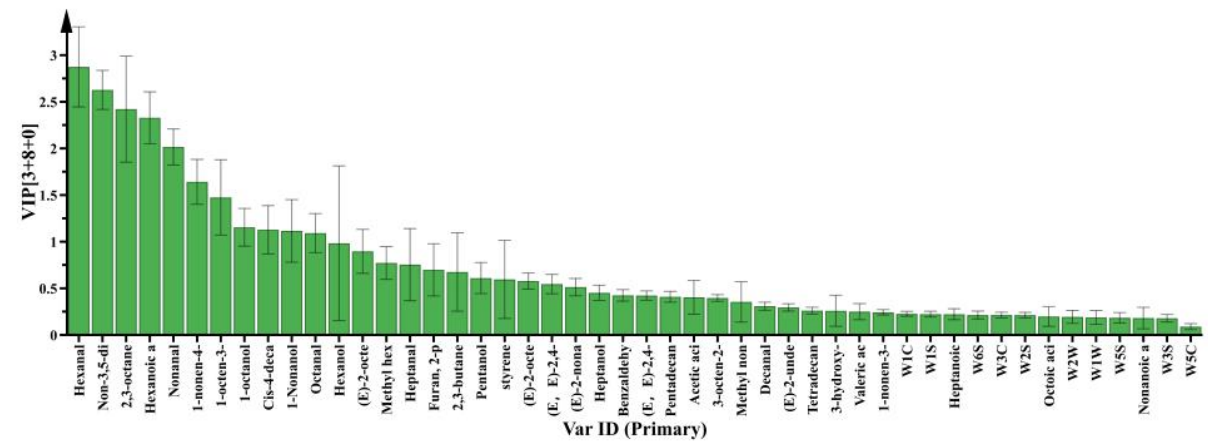

(c)

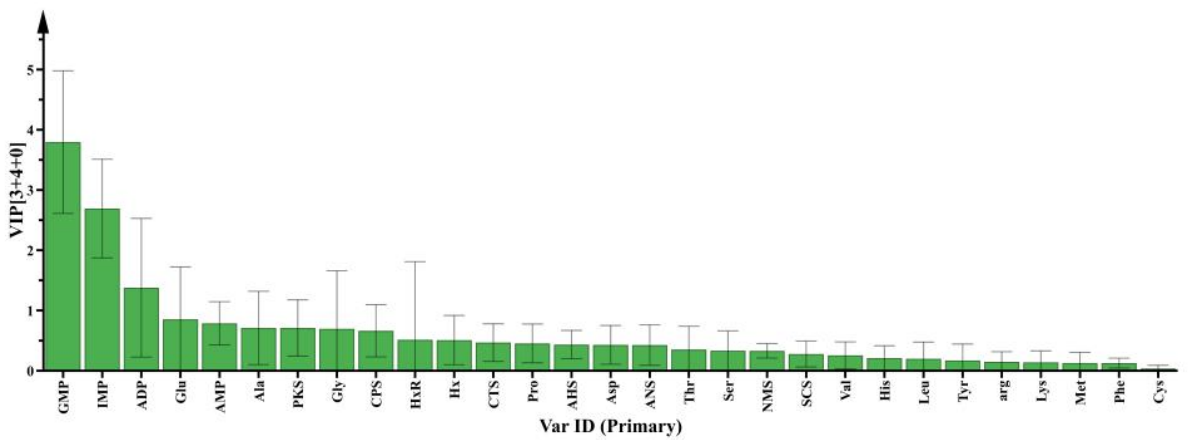

(d)

Figure 4. VIP values of volatile compounds and non-volatile compounds in raw meat at different chilling rates and different refrigeration times. (a) VIP values of volatile compounds at different chilling rates. (b) VIP values of non-volatile compounds at different chilling rates. (c) VIP values of volatile compounds at different refrigeration times. (d) VIP values of non-volatile compounds at different refrigeration times. 
The rapid chilling could significantly retard the postmortem process [7] and decrease the rate of $\mathrm{pH}$ decline [8]. In addition, lower ambient temperatures decreased the lipid oxidation [45], especially for raw meat stored at -30 and $-80{ }^{\circ} \mathrm{C}$ [27]. Hexanal, 2,3octanedione, nonanal, 1-octen-3-ol, hexanoic acid, and octanal were all regarded as the products of lipid oxidation [46], so they might be the differential volatile compounds in raw meat under different chilling rates. For non-volatile compounds, the formation of IMP was controlled by an essential enzyme adenylate deaminase (AMPD) in adenosine triphosphate (ATP) degradation [47]. The hydrolysis of IMP was controlled by acid phosphatases (ACP) and alkaline phosphatases (ALP). Lower refrigeration temperatures inhibited the activity of glycolytic enzymes and reduced the rate of ATP turnover, resulting in different IMP and GMP contents at different chilling rates [48].

\subsubsection{Differential Metabolites in Raw Meat: Effect of Refrigeration Time}

During refrigeration, volatile compounds with VIP values greater than 1.5 in raw meat included hexanal (2.87), nona-3,5-dien-2-one (2.63), 2,3-octanedione (2.42), hexanoic acid (2.32), nonanal (2.01), and 1-nonen-4-ol (1.64). For non-volatile compounds, both GMP (3.79) and IMP (2.69) were deemed to be significant with predictive VIP $>1.5$ (Figure 4c,d). Metabolites including hexanal, nona-3,5-dien-2-one, 2,3-octanedione, hexanoic acid, nonanal, 1-nonen-4-ol, 5'-GMP, and 5'-IMP were detected as the differential nonvolatile compounds at different refrigeration times. Moreover, 2,3-octanedione, nonanal, hexanoic acid, and 1-octen-3-ol have been reported as volatile compounds affected by aging in raw meat associated with lipid oxidation [49]. IMP was the differential non-volatile compounds in raw meat at different refrigeration times, and decreased with the increase of inosine, hypoxanthine, and ribose [50].

\subsection{Changes in Key Volatile and Non-Volatile Compounds in Raw Meat at Different Chilling Rates and Different Refrigeration Times \\ 3.3.1. Changes in Key Volatile Compounds}

As shown in Table 1 and Figure 3a, 38 volatile compounds were detected in raw meat, mainly including aldehydes, alcohols, acids, esters, ketones, heterocyclic, and alkanes. Hexanal (526.32-2375.77 ng/g) had the most abundant content, followed by 1-octen-3-ol (398.33-916.86 ng/g), 2,3-octanedione (127.39-858.26 ng/g), and nonanal (192.54-1095.56 ng/g). Based on OAVs and the contribution rates, 1-octen-3-ol, (E, E)2,4-decadienal, and nonanal were recognized as key volatile compounds in raw meat during refrigeration with different chilling rates. In terms of contribution rate, the contribution rate of 1-octene-3-ol at $72 \mathrm{~h}$ post-slaughter was significantly lower $(p<0.05)$ than that at other post-slaughter times at chilling rates of $1.44{ }^{\circ} \mathrm{C} / \mathrm{h}$, but the contribution rate of aldehydes was significantly higher $(p<0.05)$. When the chilling rate was $32.4^{\circ} \mathrm{C} / \mathrm{h}$, the contribution rate of aldehydes at $24 \mathrm{~h}$ post-mortem was significantly higher $(p<0.05)$ than that at other post-mortem hours, while 1-octen-3-ol was significantly lower $(p<0.05)$. (E, E)-2,4-decadienal was the highest contributing aldehyde, which enhanced the aroma of raw meat [51]. The results also showed (E, E)-2, 4-decadienal was the predominant volatile compound at $72 \mathrm{~h}$ post-slaughter when the chilling rate was $1.44{ }^{\circ} \mathrm{C} / \mathrm{h}$ and $22.2^{\circ} \mathrm{C} / \mathrm{h}$, while (E, E)-2, 4-decadienal was the largest contributor of the volatile compound at $24 \mathrm{~h}$ when the rate was $32.4^{\circ} \mathrm{C} / \mathrm{h}$. This might be due to the delayed phase of the decrease in ATP concentration associated with a rapid chilling rate $\left(32.4^{\circ} \mathrm{C} / \mathrm{h}\right)$. ATP remained almost constant during chilling at $-20^{\circ} \mathrm{C}$ or lower [52], at which temperature the breakdown of ribonucleotides, protein hydrolysis, and glycolysis would be inhibited. Conversely, some oil-derived volatiles, including (E, E)-2, 4-decadienal, were increased through the breakdown of ribonucleotides, protein hydrolysis, and glycolysis [53-55]. Therefore, the contribution rate of (E, E)-2,4-decadienal in raw meat at $24 \mathrm{~h}$ post-slaughter was higher at $32.4^{\circ} \mathrm{C} / \mathrm{h}$ than $1.44{ }^{\circ} \mathrm{C} / \mathrm{h}$. 
Table 1. Identification of volatile compounds in raw meat.

\begin{tabular}{|c|c|c|c|c|c|c|c|}
\hline \multirow{2}{*}{ Compound $^{\text {a }}$} & \multicolumn{2}{|c|}{ LRI $^{b}$} & \multirow{2}{*}{ Identification $^{\mathrm{e}}$} & \multirow{2}{*}{ Compound $^{a}$} & \multicolumn{2}{|c|}{ LRI $^{b}$} & \multirow{2}{*}{ Identification $^{\mathrm{e}}$} \\
\hline & Calculated $^{\mathrm{c}}$ & Literature $^{\mathrm{d}}$ & & & Calculated $^{\mathrm{c}}$ & Literature $^{\mathrm{d}}$ & \\
\hline Hexanal & 1076 & 1080 & MS, LRI, S & 2,3-Butanediol & 1571 & 1570 & MS, LRI \\
\hline Heptanal & 1168 & 1170 & MS, LRI & 2-Octen-1-ol, (E)- & 1606 & 1603 & MS, LRI, S \\
\hline Octanal & 1269 & 1275 & MS, LRI, S & 1-Nonen-4-ol & 1635 & $-f$ & MS \\
\hline Nonanal & 1376 & 1380 & MS, LRI & 1-Nonanol & 1657 & 1656 & MS, LRI, S \\
\hline (E)-2-Octenal & 1412 & 1416 & MS, LRI, S & 1-Nonen-3-ol & 1747 & 1555 & MS, LRI \\
\hline Decanal & 1481 & 1483 & MS, LRI, S & acetic acid & 1442 & 1441 & MS, LRI \\
\hline Benzaldehyde & 1502 & 1495 & MS, LRI, S & Pentanoic acid & 1729 & 1734 & MS, LRI \\
\hline (E)-2-Nonenal & 1518 & 1514 & MS, LRI, S & Hexanoic acid & 1835 & 1834 & MS, LRI, S \\
\hline cis-4-Decenal & 1525 & 1542 & MS, LRI & Heptanoic acid & 1966 & 1967 & MS, LRI \\
\hline (E, E)-2,4-Nonadienal & 1682 & 1687 & MS, LRI, S & Octanoic acid & 2068 & 2072 & MS, LRI \\
\hline 2-Undecenal & 1739 & 1755 & MS, LRI & Nonanoic acid & 2171 & 2174 & MS, LRI \\
\hline (E, E)-2,4-Decadienal & 1752 & 1763 & MS, LRI, S & 3-hydroxy-2-butanone & 1265 & 1259 & MS, LRI \\
\hline Tetradecanal & 1900 & 1908 & MS, LRI & 2,3-Octanedione & 1311 & 1325 & MS, LRI \\
\hline Pentadecanal & 2037 & 2042 & MS, LRI & 3-Octen-2-one & 1393 & 1414 & MS, LRI \\
\hline 1-Pentanol & 1262 & 1261 & MS, LRI & 3,5-Nonadien-2-one & 1801 & $-f$ & MS \\
\hline 1-Hexanol & 1354 & 1356 & MS, LRI, S & Hexanoic acid, methyl ester & 1170 & 1177 & MS, LRI \\
\hline 1-Octen-3-ol & 1447 & 1447 & MS, LRI, S & Nonanoic acid, methyl ester & 1477 & 1481 & MS, LRI \\
\hline 1-Heptanol & 1452 & 1458 & MS, LRI, S & Furan, 2-pentyl- & 1202 & 1213 & MS, LRI, S \\
\hline 1-Octanol & 1553 & 1554 & MS, LRI, S & styrene & 1234 & 1242 & MS, LRI \\
\hline
\end{tabular}

${ }^{a}$ Volatile compound detected in raw meat. ${ }^{b}$ Linear retention index. ${ }^{\mathrm{c}}$ Calculated data based on n-alkanes $\left(\mathrm{C}_{7}-\mathrm{C}_{40}\right) .{ }^{\mathrm{d}}$ Reported data. ${ }^{\mathrm{e}} \mathrm{MS}$, mass spectrum; LRI, linear retention index; S, confirmed by authentic aroma standards. ${ }^{\mathrm{f}}$ Not identified.

The contents of 1-octen-3-ol, (E, E)-2,4-decadienal, and nonanal in raw meat first increased and then decreased during refrigeration, and their OAVs had the same trend. Similar results were obtained from studies on Jingyuan meat [35]. 1-octen-3-ol was mainly derived from linoleic acid when amino acids and ribose interact during lipid oxidation [56], and aldehydes also could be formed through lipid oxidation [57]. Therefore, the contents of 1-octen-3-ol, (E, E)-2,4-decadienal and nonanal increased in the early post-slaughter period, which might be due to lipid oxidation of raw meat. Generally, the fatty flavor was richer under the rapid chilling rate, especially at $24 \mathrm{~h}$ postmortem. In addition, more aromatic compounds were observed in lamb meat at $72 \mathrm{~h}$ postmortem with a chilling rate of $1.44^{\circ} \mathrm{C} / \mathrm{h}$ and at $24 \mathrm{~h}$ with a chilling rate of $32.4{ }^{\circ} \mathrm{C} / \mathrm{h}$.

\subsubsection{Changes in Key Non-Volatile Compounds}

As shown in Table 2, the main free amino acids in raw meat were Glu (24.85-67.72 mg/ $100 \mathrm{~g})$, Ala (22.67-41.55 mg/100 g), which were umami and sweet, respectively. The content of 5 '-nucleotides and the corresponding nucleotides of raw meat at three chilling rates during refrigeration were shown in Table 3. 5'-GMP was the most abundant nucleotide in raw meat, ranging from 1797.17 to $2555.08 \mathrm{mg} / 100 \mathrm{~g}$. The $5^{\prime}$-IMP content was ranged from 153.41 to $722.99 \mathrm{mg} / 100 \mathrm{~g}$, and 5'-ADP content was ranged from 64.72 to $146.69 \mathrm{mg} / 100 \mathrm{~g}$. AMP, Hx, and HxR were ranged from 16.78 to $47.79 \mathrm{mg} / 100 \mathrm{~g}, 16.71$ to $33.35 \mathrm{mg} / 100 \mathrm{~g}$, and 12.72 to $20.01 \mathrm{mg} / 100 \mathrm{~g}$, respectively. Based on TAVs, Asp, Glu, 5'-GMP, 5'-IMP, and 5'-AMP were the key non-volatile compounds in raw meat during refrigeration with different chilling rates.

As shown in Figure 5, the rate of decrease in IMP and GMP contents with a chilling rate of $32.4^{\circ} \mathrm{C} / \mathrm{h}$ was significantly lower $(p<0.05)$ than that with $1.44{ }^{\circ} \mathrm{C} / \mathrm{h}$. When the chilling rate was $1.44^{\circ} \mathrm{C} / \mathrm{h}$, the contents of UAAs at $24 \mathrm{~h}$ after slaughter were significantly lower $(p<0.05)$ than that at other times. However, at 22.2 and $32.4{ }^{\circ} \mathrm{C} / \mathrm{h}$, the contents of UAAs were the lowest $(p<0.05)$ at $72 \mathrm{~h}$ after slaughter. To get a better view of the umami intensity of raw meat, the EUCs of umami amino acids and taste nucleotides were calculated. As could be clearly observed in Figure 6, the EUCs and contents of UAAs showed the same trend at different chilling rates. The reduction in the contents of UAAs and FAAs might be related to the enhanced glycolysis and the rapid decrease in $\mathrm{pH}$ and ATP content during refrigeration. Several studies showed that rapid chilling rate could significantly inhibit $\mathrm{pH}$ decline, ATP consumption and suppress glycolysis [21,58,59]. 
Table 2. Contents (mg/100 g) of free amino acid in raw meat at different chilling rates during refrigeration.

\begin{tabular}{|c|c|c|c|c|c|c|c|c|c|}
\hline \multirow[b]{2}{*}{$\begin{array}{l}\text { Content } \\
\text { (mg/100 g) }\end{array}$} & \multirow[b]{2}{*}{ Flavor Trait } & \multirow[b]{2}{*}{ Chilling Rate } & \multicolumn{4}{|c|}{ Storage Time } & \multicolumn{3}{|c|}{$p$-Value } \\
\hline & & & $1 \mathrm{~h}$ & $24 \mathrm{~h}$ & $72 \mathrm{~h}$ & $120 \mathrm{~h}$ & Storage Time & Chilling Rate & $\begin{array}{c}\text { Storage Time } \times \\
\text { Chilling Rate }\end{array}$ \\
\hline Asp & Umami & $\begin{array}{l}1.44^{\circ} \mathrm{C} / \mathrm{h} \\
22.2^{\circ} \mathrm{C} / \mathrm{h} \\
32.4^{\circ} \mathrm{C} / \mathrm{h}\end{array}$ & $\begin{array}{c}4.6 \pm 0.74 \mathrm{Aa} \\
3.21 \pm 0.17^{\mathrm{Ab}} \\
1.63 \pm 0.14^{\mathrm{Ac}}\end{array}$ & $\begin{array}{c}3.52 \pm 1.23^{\mathrm{Aa}} \\
1.1 \pm 0.17^{\mathrm{Cc}} \\
2.2 \pm 0.54^{\mathrm{Ab}}\end{array}$ & $\begin{array}{c}3.36 \pm 0.35^{\mathrm{ABa}} \\
3.46 \pm 0.28^{\mathrm{Aa}} \\
1.37 \pm 0.10^{\mathrm{Bb}}\end{array}$ & $\begin{array}{l}2.77 \pm 0.09 \mathrm{Ba} \\
2.85 \pm 1.00^{\mathrm{Ba}} \\
1.78 \pm 0.17 \mathrm{Ab}\end{array}$ & 0.004 & 0.004 & 0.000 \\
\hline Glu & Umami & $\begin{array}{l}1.44^{\circ} \mathrm{C} / \mathrm{h} \\
22.2^{\circ} \mathrm{C} / \mathrm{h} \\
32.4^{\circ} \mathrm{C} / \mathrm{h}\end{array}$ & $\begin{array}{c}40.67 \pm 4.75^{\mathrm{Bb}} \\
66.2 \pm 4.44^{\mathrm{Aa}} \\
48.66 \pm 0.22^{\mathrm{Ab}}\end{array}$ & $\begin{array}{l}33.81 \pm 1.55^{\mathrm{Cc}} \\
67.72 \pm 4.05^{\mathrm{Aa}} \\
55.38 \pm 8.30^{\mathrm{Ab}}\end{array}$ & $\begin{array}{l}57.08 \pm 6.69^{\mathrm{Aa}} \\
41.78 \pm 3.23^{\mathrm{Bb}} \\
24.85 \pm 6.05^{\mathrm{Bc}}\end{array}$ & $\begin{array}{c}62.76 \pm 10.62 \mathrm{Aa} \\
67.17 \pm 3.48^{\mathrm{Aa}} \\
44.21 \pm 7.59 \mathrm{Ab}\end{array}$ & 0.000 & 0.000 & 0.000 \\
\hline Thr & Sweet & $\begin{array}{l}1.44^{\circ} \mathrm{C} / \mathrm{h} \\
22.2^{\circ} \mathrm{C} / \mathrm{h} \\
32.4^{\circ} \mathrm{C} / \mathrm{h}\end{array}$ & $\begin{array}{c}2.83 \pm 0.36^{\mathrm{ABa}} \\
2.69 \pm 0.24 \mathrm{Ca} \\
2.47 \pm 0.07^{\mathrm{Ba}}\end{array}$ & $\begin{array}{l}2.27 \pm 0.37^{\mathrm{Bb}} \\
3.55 \pm 0.32^{\mathrm{Ba}} \\
3.49 \pm 0.72^{\mathrm{Aa}}\end{array}$ & $\begin{array}{l}1.85 \pm 0.02 \mathrm{Cb} \\
2.94 \pm 0.12 \mathrm{Ca} \\
1.81 \pm 0.35 \mathrm{Cb}\end{array}$ & $\begin{array}{l}3.29 \pm 0.64 \mathrm{Ab} \\
4.19 \pm 0.16^{\mathrm{Aa}} \\
3.03 \pm 0.48^{\mathrm{Ab}}\end{array}$ & 0.000 & 0.001 & 0.017 \\
\hline Gly & Sweet & $\begin{array}{l}1.44^{\circ} \mathrm{C} / \mathrm{h} \\
22.2^{\circ} \mathrm{C} / \mathrm{h} \\
32.4^{\circ} \mathrm{C} / \mathrm{h}\end{array}$ & $\begin{array}{l}14.68 \pm 0.97^{\mathrm{Aa}} \\
10.47 \pm 0.66^{\mathrm{Bb}} \\
14.33 \pm 0.23^{\mathrm{Ba}}\end{array}$ & $\begin{array}{c}11.8 \pm 1.48^{\mathrm{Bc}} \\
14.68 \pm 0.86^{\mathrm{Ab}} \\
18.35 \pm 2.66^{\mathrm{Aa}}\end{array}$ & $\begin{array}{c}9.38 \pm 0.12^{\mathrm{Bb}} \\
8.45 \pm 0.49^{\mathrm{Cb}} \\
17.38 \pm 2.95^{\mathrm{Aa}}\end{array}$ & $\begin{array}{c}12.83 \pm 2.09 \mathrm{ABb} \\
14.63 \pm 0.54 \mathrm{Aa} \\
14.94 \pm 2.19 \mathrm{ABa}\end{array}$ & 0.010 & 0.000 & 0.002 \\
\hline Ala & Sweet & $\begin{array}{l}1.44^{\circ} \mathrm{C} / \mathrm{h} \\
22.2^{\circ} \mathrm{C} / \mathrm{h} \\
32.4^{\circ} \mathrm{C} / \mathrm{h}\end{array}$ & $\begin{array}{l}41.55 \pm 3.66^{\mathrm{Aa}} \\
22.67 \pm 1.23^{\mathrm{Bc}} \\
27.84 \pm 0.42^{\mathrm{Bb}}\end{array}$ & $\begin{array}{l}34.14 \pm 3.52^{\mathrm{Bb}} \\
30.07 \pm 2.12^{\mathrm{Ac}} \\
38.54 \pm 6.05^{\mathrm{Aa}}\end{array}$ & $\begin{array}{c}30.81 \pm 0.13 \mathrm{Ca} \\
27.61 \pm 1.46^{\mathrm{Ab}} \\
29.14 \pm 4.28 \mathrm{ABab}\end{array}$ & $\begin{array}{c}34.43 \pm 5.69 \mathrm{Ba} \\
30.65 \pm 1.93 \mathrm{Ab} \\
31.12 \pm 5.13 \mathrm{ABab}\end{array}$ & 0.086 & 0.001 & 0.014 \\
\hline Lys & Sweet/Bitter & $\begin{array}{l}1.44^{\circ} \mathrm{C} / \mathrm{h} \\
22.2^{\circ} \mathrm{C} / \mathrm{h} \\
32.4^{\circ} \mathrm{C} / \mathrm{h}\end{array}$ & $\begin{array}{l}2.29 \pm 0.29 \mathrm{Aa} \\
2.11 \pm 0.15^{\mathrm{Ca}} \\
1.84 \pm 0.19^{\mathrm{Bb}}\end{array}$ & $\begin{array}{l}1.72 \pm 0.19^{\mathrm{Bb}} \\
2.82 \pm 0.11^{\mathrm{Ba}} \\
2.53 \pm 0.42^{\mathrm{Aa}}\end{array}$ & $\begin{array}{l}1.91 \pm 0.02^{\mathrm{Bb}} \\
2.45 \pm 0.41^{\mathrm{Ba}} \\
2.48 \pm 0.23^{\mathrm{Aa}}\end{array}$ & $\begin{array}{l}2.98 \pm 0.53^{\mathrm{Ab}} \\
3.54 \pm 0.04 \mathrm{Aa} \\
2.73 \pm 0.45^{\mathrm{Ab}}\end{array}$ & 0.000 & 0.004 & 0.012 \\
\hline Pro & Sweet/Bitter & $\begin{array}{l}1.44^{\circ} \mathrm{C} / \mathrm{h} \\
22.2^{\circ} \mathrm{C} / \mathrm{h} \\
32.4^{\circ} \mathrm{C} / \mathrm{h}\end{array}$ & $\begin{array}{c}4.4 \pm 0.06^{\mathrm{Aa}} \\
4.51 \pm 0.14^{\mathrm{Ba}} \\
4.17 \pm 0.23^{\mathrm{Bb}}\end{array}$ & $\begin{array}{l}4.33 \pm 0.22 \mathrm{Ab} \\
6.04 \pm 0.54 \mathrm{Aa} \\
5.4 \pm 0.81^{\mathrm{Aab}}\end{array}$ & $\begin{array}{c}3.93 \pm 0.15^{\mathrm{Ba}} \\
3.61 \pm 0.49^{\mathrm{Bab}} \\
3.22 \pm 0.1 \mathrm{Cb}\end{array}$ & $\begin{array}{c}4.94 \pm 0.86^{\mathrm{Ab}} \\
6.7 \pm 0.55^{\mathrm{Aa}} \\
4.33 \pm 0.27^{\mathrm{Bb}}\end{array}$ & 0.000 & 0.000 & 0.002 \\
\hline Val & Sweet/Bitter & $\begin{array}{l}1.44^{\circ} \mathrm{C} / \mathrm{h} \\
22.2^{\circ} \mathrm{C} / \mathrm{h} \\
32.4^{\circ} \mathrm{C} / \mathrm{h}\end{array}$ & $\begin{array}{l}3.03 \pm 0.42^{\mathrm{Aa}} \\
2.44 \pm 0.13^{\mathrm{Cb}} \\
1.86 \pm 0.14^{\mathrm{Bc}}\end{array}$ & $\begin{array}{c}2.53 \pm 0.32 \mathrm{Bb} \\
3.08 \pm 0.2^{\mathrm{Ba}} \\
2.29 \pm 0.41^{\mathrm{Ab}}\end{array}$ & $\begin{array}{l}1.33 \pm 0.21 \mathrm{Cb} \\
2.35 \pm 0.06^{\mathrm{Ca}} \\
2.12 \pm 0.31^{\mathrm{Aa}}\end{array}$ & $\begin{array}{c}2.81 \pm 0.47^{\mathrm{Bb}} \\
3.43 \pm 0.2^{\mathrm{Aa}} \\
2.38 \pm 0.4^{\mathrm{Ab}}\end{array}$ & 0.000 & 0.000 & 0.003 \\
\hline
\end{tabular}


Table 2. Cont.

\begin{tabular}{|c|c|c|c|c|c|c|c|c|c|}
\hline \multirow{2}{*}{$\begin{array}{l}\text { Content } \\
(\mathrm{mg} / 100 \mathrm{~g})\end{array}$} & \multirow[b]{2}{*}{ Flavor Trait } & \multirow[b]{2}{*}{ Chilling Rate } & \multicolumn{4}{|c|}{ Storage Time } & \multicolumn{3}{|c|}{$p$-Value } \\
\hline & & & $1 \mathrm{~h}$ & $24 \mathrm{~h}$ & $72 \mathrm{~h}$ & $120 \mathrm{~h}$ & Storage Time & Chilling Rate & $\begin{array}{c}\text { Storage Time } \\
\text { Chilling Rate }\end{array}$ \\
\hline \multirow{3}{*}{ Leu } & \multirow{3}{*}{ Bitter } & $1.44^{\circ} \mathrm{C} / \mathrm{h}$ & $3.82 \pm 0.4^{\mathrm{Aa}}$ & $3.15 \pm 0.37 \mathrm{Aa}$ & $1.82 \pm 0.15^{\mathrm{Bc}}$ & $3.73 \pm 0.64^{\mathrm{Ab}}$ & \multirow{3}{*}{0.000} & \multirow{3}{*}{0.231} & \multirow{3}{*}{0.000} \\
\hline & & $22.2^{\circ} \mathrm{C} / \mathrm{h}$ & $2.51 \pm 0.22^{\mathrm{Bb}}$ & $3.35 \pm 0.25^{\mathrm{Aa}}$ & $2.91 \pm 0.12^{\mathrm{Bb}}$ & $4.95 \pm 0.34 \mathrm{Aa}$ & & & \\
\hline & & $32.4{ }^{\circ} \mathrm{C} / \mathrm{h}$ & $2.28 \pm 0.15^{\mathrm{Bb}}$ & $3.18 \pm 0.48^{\mathrm{Aa}}$ & $3.6 \pm 0.48^{\mathrm{Aa}}$ & $3.6 \pm 0.66^{\mathrm{Ab}}$ & & & \\
\hline \multirow[b]{2}{*}{ Tyr } & \multirow[b]{2}{*}{ Bitter } & $1.44^{\circ} \mathrm{C} / \mathrm{h}$ & $2.62 \pm 0.24^{\mathrm{Aa}}$ & $2.22 \pm 0.1^{\mathrm{Bb}}$ & $1.66 \pm 0.04^{\mathrm{Cb}}$ & $2.85 \pm 0.45^{\mathrm{Ab}}$ & \multirow[b]{2}{*}{0.000} & \multirow[b]{2}{*}{0.004} & \multirow[b]{2}{*}{0.002} \\
\hline & & $22.2^{\circ} \mathrm{C} / \mathrm{h}$ & $2.09 \pm 0.14^{\mathrm{Cb}}$ & $2.91 \pm 0.19^{\mathrm{Ba}}$ & $2.7 \pm 0.16^{\mathrm{Ba}}$ & $3.82 \pm 0.19^{\mathrm{Aa}}$ & & & \\
\hline \multirow{3}{*}{ Phe } & \multirow{3}{*}{ Bitter } & $1.44^{\circ} \mathrm{C} / \mathrm{h}$ & $2.48 \pm 0.33^{\mathrm{Ba}}$ & $2.68 \pm 0.06^{\mathrm{Ba}}$ & $2.57 \pm 0.34^{\mathrm{Bb}}$ & $3.27 \pm 0.34 \mathrm{Aab}$ & \multirow{3}{*}{0.000} & \multirow{3}{*}{0.183} & \multirow{3}{*}{0.034} \\
\hline & & $22.2^{\circ} \mathrm{C} / \mathrm{h}$ & $2.25 \pm 0.17 \mathrm{Ca}$ & $2.88 \pm 0.16^{\mathrm{Ba}}$ & $2.87 \pm 0.25^{\mathrm{Bab}}$ & $3.72 \pm 0.29 \mathrm{Aa}$ & & & \\
\hline & & $32.4^{\circ} \mathrm{C} / \mathrm{h}$ & $2.39 \pm 0.12^{\mathrm{Ba}}$ & $2.96 \pm 0.13 \mathrm{Aa}$ & $3.18 \pm 0.12 \mathrm{Aa}$ & $3.14 \pm 0.34^{\mathrm{Ab}}$ & & & \\
\hline \multirow{3}{*}{ His } & \multirow{3}{*}{ Bitter } & $1.44^{\circ} \mathrm{C} / \mathrm{h}$ & $1.74 \pm 0.25^{\mathrm{Aa}}$ & $0.88 \pm 0.32^{\mathrm{Bb}}$ & $0.53 \pm 0.21^{\mathrm{Bb}}$ & $1.41 \pm 0.51 \mathrm{ABa}$ & \multirow{3}{*}{0.015} & \multirow{3}{*}{0.005} & \multirow{3}{*}{0.006} \\
\hline & & $22.2^{\circ} \mathrm{C} / \mathrm{h}$ & $0.63 \pm 0.39^{\mathrm{Bb}}$ & $1.02 \pm 0.22 \mathrm{Aab}$ & $0.33 \pm 0.03^{\mathrm{Cb}}$ & $0.93 \pm 0.05^{\mathrm{Ab}}$ & & & \\
\hline & & $32.4^{\circ} \mathrm{C} / \mathrm{h}$ & $0.74 \pm 0.49^{\mathrm{Bb}}$ & $1.37 \pm 0.14^{\mathrm{Aa}}$ & $1.17 \pm 0.17^{\mathrm{Aa}}$ & $1.24 \pm 0.23^{\mathrm{Aa}}$ & & & \\
\hline \multirow{2}{*}{ Arg } & \multirow{2}{*}{ Bitter/Sweet } & $1.44^{\circ} \mathrm{C} / \mathrm{h}$ & $5.02 \pm 0.56^{\mathrm{Aa}}$ & $3.97 \pm 0.47^{\mathrm{Cb}}$ & $4.51 \pm 0.13^{\mathrm{Ba}}$ & $5.29 \pm 0.91$ Aab & \multirow{2}{*}{0.009} & \multirow{2}{*}{0.162} & \multirow{2}{*}{0.008} \\
\hline & & $32.4^{\circ} \mathrm{C} / \mathrm{h}$ & $3.86 \pm 0.86^{\mathrm{Ab}}$ & $4.22 \pm 0.71 \mathrm{Aab}$ & $4.52 \pm 0.49 \mathrm{Aa}$ & $4.37 \pm 0.58 \mathrm{Ab}$ & & & \\
\hline \multirow{3}{*}{ Cys } & & $1.44^{\circ} \mathrm{C} / \mathrm{h}$ & $0.13 \pm 0.04^{\mathrm{Aa}}$ & $0.08 \pm 0.03^{\mathrm{Ac}}$ & $0.19 \pm 0 \mathrm{Aa}$ & $0.23 \pm 0.07^{\mathrm{Aa}}$ & & & \\
\hline & Bitter/Sweet/ & $22.2^{\circ} \mathrm{C} / \mathrm{h}$ & $0.06 \pm 0.05^{\mathrm{Ac}}$ & $0.13 \pm 0.03^{\mathrm{Ab}}$ & $0.07 \pm 0.08^{\mathrm{Ab}}$ & $0.18 \pm 0.07^{\mathrm{Ab}}$ & 0.043 & 0.061 & 0.001 \\
\hline & & $32.4^{\circ} \mathrm{C} / \mathrm{h}$ & $0.09 \pm 0 \mathrm{Db}$ & $0.19 \pm 0.03^{\mathrm{Aa}}$ & $0.12 \pm 0^{\mathrm{Bb}}$ & $0.07 \pm 0^{\mathrm{Cc}}$ & & & \\
\hline & & $1.44^{\circ} \mathrm{C} / \mathrm{h}$ & $0.95 \pm 0.06^{\mathrm{Aa}}$ & $0.79 \pm 0.16^{\mathrm{Ab}}$ & $0.45 \pm 0.05^{\mathrm{Bc}}$ & $1.12 \pm 0.18^{\mathrm{Ab}}$ & & & \\
\hline Met & Bitter/Sweet/ & $22.2^{\circ} \mathrm{C} / \mathrm{h}$ & $0.65 \pm 0.21 \mathrm{Cb}$ & $1.11 \pm 0.11^{\mathrm{Ba}}$ & $0.9 \pm 0.04 \mathrm{Db}$ & $2.29 \pm 0.18^{\mathrm{Aa}}$ & 0.000 & 0.000 & 0.000 \\
\hline & Sulturous & $32.4^{\circ} \mathrm{C} / \mathrm{h}$ & $0.79 \pm 0.09 \mathrm{Bb}$ & $1.2 \pm 0.17 \mathrm{Aa}$ & $1.28 \pm 0.12 \mathrm{Aa}$ & $1.46 \pm 0.29 \mathrm{Ab}$ & & & \\
\hline & & $1.44^{\circ} \mathrm{C} / \mathrm{h}$ & $135.18 \pm 13.53 \mathrm{Aa}$ & $111.48 \pm 6.93^{\mathrm{Bb}}$ & $123.98 \pm 5.93 \mathrm{Aa}$ & $148.89 \pm 24.62 \mathrm{Ab}$ & & & \\
\hline FAA & UN & $22.2^{\circ} \mathrm{C} / \mathrm{h}$ & $128.77 \pm 7.69 \mathrm{Bb}$ & $149.35 \pm 9.17 \mathrm{Aa}$ & $108.93 \pm 6.03 \mathrm{Cb}$ & $159.9 \pm 7.23 \mathrm{Aa}$ & 0.001 & 0.445 & 0.016 \\
\hline & & $32.4^{\circ} \mathrm{C} / \mathrm{h}$ & $118.59 \pm 0.75^{\mathrm{Bc}}$ & $148.82 \pm 22.3^{\mathrm{Aa}}$ & $102.98 \pm 15.4^{\mathrm{Cb}}$ & $125.65 \pm 19.67 \mathrm{Ac}$ & & & \\
\hline
\end{tabular}

$\mathrm{a}, \mathrm{b}, \mathrm{c}$ Different lowercase letters indicate significant differences between chilling rates $(p<0.05)$. ${ }^{\mathrm{A}, \mathrm{B}, \mathrm{C}, \mathrm{D}}$ Different capital letters indicate significant differences between refrigeration times $(p<0.05)$. 
Table 3. Contents (mg/100 g) of 5'-nucleotides in raw meat at different chilling rates during refrigeration.

\begin{tabular}{|c|c|c|c|c|c|c|c|c|c|}
\hline \multirow{2}{*}{$\begin{array}{l}\text { Content } \\
(\mathrm{mg} / 100 \mathrm{~g})\end{array}$} & \multirow[b]{2}{*}{ Flavor Trait } & \multirow[b]{2}{*}{ Chilling Rate } & \multicolumn{4}{|c|}{ Storage Time } & \multicolumn{3}{|c|}{$p$-Value } \\
\hline & & & $1 \mathrm{~h}$ & $24 \mathrm{~h}$ & $72 \mathrm{~h}$ & $120 \mathrm{~h}$ & $\begin{array}{l}\text { Storage } \\
\text { Time }\end{array}$ & $\begin{array}{c}\text { Chilling } \\
\text { Rate }\end{array}$ & $\begin{array}{c}\text { Storage Time } \times \\
\text { Chilling Rate }\end{array}$ \\
\hline ADP & UN & $\begin{array}{l}1.44^{\circ} \mathrm{C} / \mathrm{h} \\
22.2^{\circ} \mathrm{C} / \mathrm{h} \\
32.4^{\circ} \mathrm{C} / \mathrm{h}\end{array}$ & $\begin{array}{c}64.72 \pm 6.13 \mathrm{Cb} \\
106.13 \pm 2.11^{\mathrm{Ba}} \\
106.76 \pm 12.69 \mathrm{Ba}\end{array}$ & $\begin{array}{l}103.76 \pm 7.11^{\mathrm{Ba}} \\
71.98 \pm 0.83^{\mathrm{Cb}} \\
76.95 \pm 8.73^{\mathrm{Cb}}\end{array}$ & $\begin{array}{c}113.22 \pm 6.96^{\mathrm{Ba}} \\
85.12 \pm 0.98^{\mathrm{Cb}} \\
102.29 \pm 11.1^{\mathrm{Ba}}\end{array}$ & $\begin{array}{c}140.56 \pm 0.89 \mathrm{Aa} \\
146.69 \pm 14.59 \mathrm{Aa} \\
140.09 \pm 11.13 \mathrm{Aa}\end{array}$ & 0.000 & 0.048 & 0.002 \\
\hline AMP & Umami & $\begin{array}{l}1.44^{\circ} \mathrm{C} / \mathrm{h} \\
22.2^{\circ} \mathrm{C} / \mathrm{h} \\
32.4^{\circ} \mathrm{C} / \mathrm{h}\end{array}$ & $\begin{array}{c}27.19 \pm 0.9^{\mathrm{Ca}} \\
16.78 \pm 0.41 \mathrm{Dc} \\
23.99 \pm 4.49 \mathrm{Db}\end{array}$ & $\begin{array}{l}37.48 \pm 3.98 \mathrm{Aa} \\
34.42 \pm 0.82^{\mathrm{Ba}} \\
37.94 \pm 2.95^{\mathrm{Ba}}\end{array}$ & $\begin{array}{l}36.17 \pm 1.12 \mathrm{Ac} \\
40.97 \pm 0.97 \mathrm{Ab} \\
47.79 \pm 5.87 \mathrm{Aa}\end{array}$ & $\begin{array}{c}29.41 \pm 1.69^{\mathrm{Bb}} \\
24 \pm 0.24^{\mathrm{Cc}} \\
33.16 \pm 0.21^{\mathrm{Ca}}\end{array}$ & 0.000 & 0.000 & 0.000 \\
\hline GMP & Umami/Sweet & $\begin{array}{l}1.44^{\circ} \mathrm{C} / \mathrm{h} \\
22.2^{\circ} \mathrm{C} / \mathrm{h} \\
32.4^{\circ} \mathrm{C} / \mathrm{h}\end{array}$ & $\begin{array}{c}2430.04 \pm 194.1^{\mathrm{Ac}} \\
2660.13 \pm 22.5^{\mathrm{Aa}} \\
2526.15 \pm 83.82^{\mathrm{Ab}}\end{array}$ & $\begin{array}{c}2197.66 \pm 249.65^{\mathrm{Ac}} \\
2555.08 \pm 29.53^{\mathrm{Ba}} \\
2432.85 \pm 185.17^{\mathrm{Ab}}\end{array}$ & $\begin{array}{c}2056.68 \pm 61.18^{\mathrm{Bb}} \\
2324.4 \pm 22.27^{\mathrm{Ca}} \\
2457.26 \pm 305.49^{\mathrm{Aa}}\end{array}$ & $\begin{array}{c}1797.17 \pm 8.92 \mathrm{Cb} \\
2003.88 \pm 22.97 \mathrm{Da} \\
2090.01 \pm 33.49^{\mathrm{Ba}}\end{array}$ & 0.000 & 0.000 & 0.000 \\
\hline IMP & Umami & $\begin{array}{l}1.44^{\circ} \mathrm{C} / \mathrm{h} \\
22.2^{\circ} \mathrm{C} / \mathrm{h} \\
32.4^{\circ} \mathrm{C} / \mathrm{h}\end{array}$ & $\begin{array}{l}722.99 \pm 54.07 \mathrm{Aa} \\
494.55 \pm 14.17 \mathrm{Ab} \\
438.62 \pm 27.43 \mathrm{Ab}\end{array}$ & $\begin{array}{c}296 \pm 34.4^{\mathrm{Bb}} \\
366.11 \pm 15.58^{\mathrm{Ba}} \\
309.9 \pm 21.54^{\mathrm{Ba}}\end{array}$ & $\begin{array}{c}295.93 \pm 2.99 \mathrm{Ba} \\
288.36 \pm 13.61 \mathrm{Ca} \\
284.74 \pm 28.52 \mathrm{Ca}\end{array}$ & $\begin{array}{c}153.41 \pm 26.25^{\mathrm{Cb}} \\
239.94 \pm 5.81^{\mathrm{Da}} \\
256.37 \pm 19.75^{\mathrm{Da}}\end{array}$ & 0.000 & 0.000 & 0.000 \\
\hline Hx & Bitter & $\begin{array}{l}1.44^{\circ} \mathrm{C} / \mathrm{h} \\
22.2^{\circ} \mathrm{C} / \mathrm{h} \\
32.4^{\circ} \mathrm{C} / \mathrm{h}\end{array}$ & $\begin{array}{l}23.61 \pm 1.05^{\mathrm{Aa}} \\
22.21 \pm 6.07^{\mathrm{Ba}} \\
25.97 \pm 1.34 \mathrm{Aa}\end{array}$ & $\begin{array}{c}25.87 \pm 5.42 \mathrm{Aa} \\
31.95 \pm 1.3^{\mathrm{Aa}} \\
28.26 \pm 2.06^{\mathrm{Aa}}\end{array}$ & $\begin{array}{c}23.98 \pm 2.34 \mathrm{Ac} \\
33.35 \pm 0.75 \mathrm{Aa} \\
27.2 \pm 2.87^{\mathrm{Ab}}\end{array}$ & $\begin{array}{l}24.94 \pm 0.21 \mathrm{Ab} \\
23.39 \pm 0.22 \mathrm{Bb} \\
28.65 \pm 7.99 \mathrm{Aa}\end{array}$ & 0.000 & 0.000 & 0.054 \\
\hline
\end{tabular}

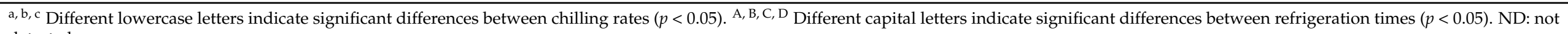
detected. 


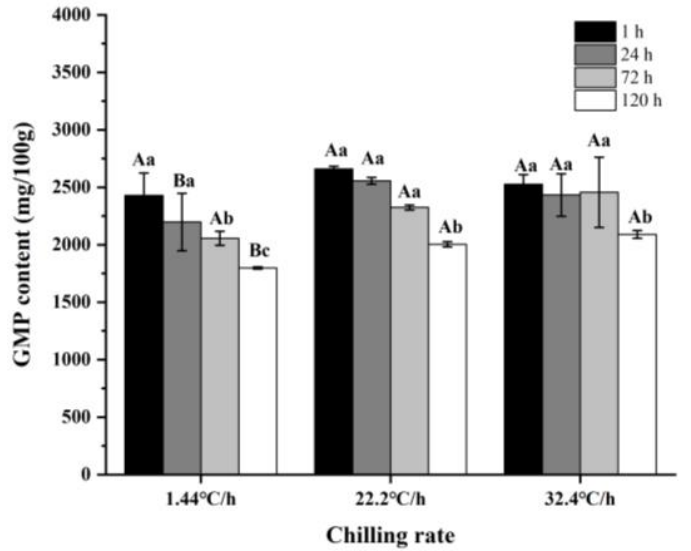

(a)

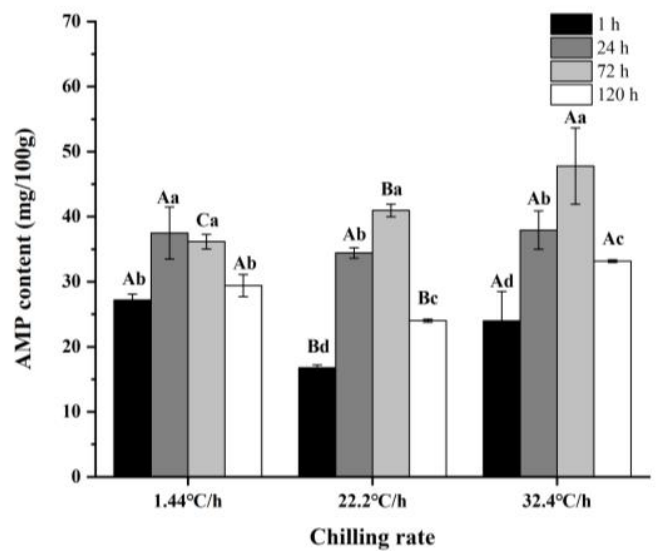

(b)

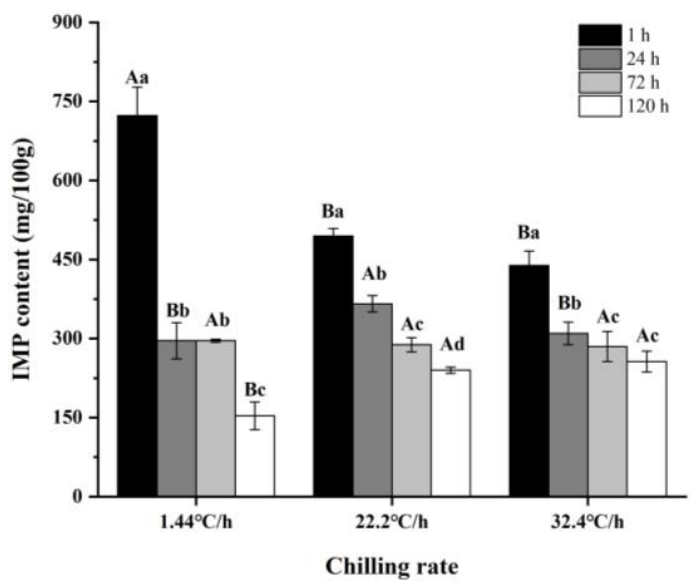

(c)

Figure 5. Contents of $5^{\prime}$-nucleotide in raw meat at different chilling rates during refrigeration. (a) Contents of $5^{\prime}$-guanylic acid (5'-GMP). (b) Contents of $5^{\prime}$-Adenosine monophosphate (5'-AMP). (c) Contents of $5^{\prime}$-inosine monophosphate (5'-IMP).

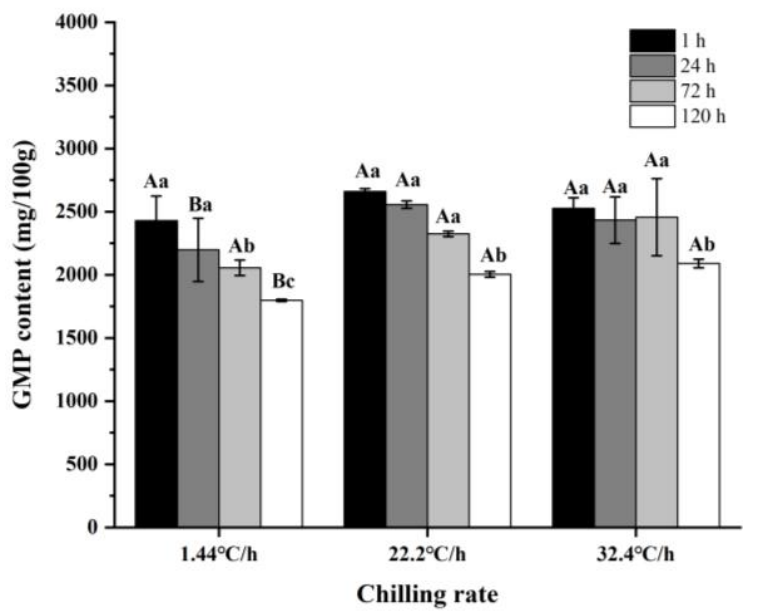

Figure 6. EUCs of non-volatile compounds in raw meat at different chilling rates during refrigeration.

As refrigeration time was extended, the contents of $5^{\prime}$-IMP and 5'-GMP decreased. The content of $5^{\prime}$-AMP increased first and then decreased, while both the contents of UAAs and FAAs and the EUCs of MSG-like components first decreased and then increased during refrigeration. During the conversion of animal muscle into meat, protein hydrolysis was released by the action of muscle proteases (calpain, histopeptidase, and multicatalytic 
protease complexes), which would produce intermediate polypeptides. Under the role of exopeptidases (dipeptidyl peptidase and tripeptidyl peptidase), aminopeptidase, and carboxypeptidase, the peptide was further hydrolyzed to produce small peptides and free amino acids $[60,61]$. UAAs and FAAs contents had a similar trend of decreasing and then increasing during rigor mortis, the reduction in the contents might be attributed to the enhanced glycolysis and the rapid decrease in $\mathrm{pH}$ and ATP content after slaughter [62]. The activation of enzymes such as calpain accelerated the hydrolysis of proteins, leading to an increase in the contents of free amino acids. ATP in raw meat was decomposed into adenosine diphosphate (ADP) under the action of ATPase, and then ADP was catabolized to AMP and IMP by the action of creatine kinase and adenylate dehydrogenase. IMP was not stable and prone to produce Inosine (HxR) and hypoxanthine $(\mathrm{Hx})$ by nucleoside hydrolase [50], which caused the IMP to continue to break down during refrigeration.

\section{Conclusions}

In summary, both chilling rates and refrigeration times affected the volatile and nonvolatile compounds of raw meat. The present study also potentially established a method to identify raw meat with different chilling rates and refrigeration times based on volatile and non-volatile compounds analysis combined with OPLS-DA. 1-octen-3-ol, (E, E)-2,4decadienal, Asp, Glu, 5'-GMP, 5'-IMP, and 5'-AMP were identified as the key volatile and non-volatile compounds. The rapid chilling rate resulted in more aromatic compounds in raw meat, especially for samples refrigerated for $24 \mathrm{~h}$. Raw lamb meat chilled at $1.44^{\circ} \mathrm{C} / \mathrm{h}$ had more aromatic and umami compounds at $72 \mathrm{~h}$ after slaughter, and those chilled at $32.4^{\circ} \mathrm{C} / \mathrm{h}$ had more aromatic and umami compounds at $24 \mathrm{~h}$. It was concluded that rapid chilling could be a potential method to preserve and even enhance the flavor of raw meat. This result might be further explained by the ability of rapid chilling to retard adenosine triphosphate hydrolysis, decelerate protein derogation, lipolysis, and fat oxidation.

Author Contributions: Conceptualization, Z.W. and D.Z.; methodology, C.X.; formal analysis, C.X.; investigation, C.X.; resources, C.L.; data curation, C.X.; writing-original draft preparation, C.X.; writing-review and editing, S.L., H.L., Z.W. and F.F.; visualization, Z.W.; supervision, Z.W. and D.Z.; project administration, Z.W. and D.Z.; funding acquisition, D.Z. All authors have read and agreed to the published version of the manuscript.

Funding: This research was funded by the Key Program of the National Natural Science Foundation of China (32030086), the Agricultural Science and Technology Innovation Program (CAAS-ASTIP2020-IFST).

Institutional Review Board Statement: Not applicable.

Informed Consent Statement: Not applicable.

Data Availability Statement: The data presented in this study are available on request from the corresponding author.

Conflicts of Interest: The authors declare no conflict of interest.

\section{References}

1. Khan, M.I.; Jo, C.; Tariq, M.R. Meat flavor precursors and factors influencing flavor precursors-A systematic review. Meat Sci. 2015, 110, 278-284. [CrossRef]

2. Bueno, M.; Resconi, V.C.; Campo, M.M.; Ferreira, V.; Escudero, A. Development of a robust HS-SPME-GC-MS method for the analysis of solid food samples. Analysis of volatile compounds in fresh raw beef of differing lipid oxidation degrees. Food Chem. 2019, 281, 49-56. [CrossRef] [PubMed]

3. Gorbatov, V.M.; Lyaskovskaya, Y.N. Review of the flavour-contributing volatiles and water-soluble non-volatiles in pork meat and derived products. Meat Sci. 1980, 4, 209-225. [CrossRef]

4. Neethling, J.; Hoffman, L.C.; Muller, M. Factors influencing the flavour of game meat: A review. Meat Sci. 2016, 113, 139-153. [CrossRef] [PubMed]

5. Li, C.B.; Chen, Y.J.; Xu, X.L.; Huang, M.; Hu, T.J.; Zhou, G.H. Effects of low-voltage electrical stimulation and rapid chilling on meat quality characteristics of Chinese Yellow crossbred bulls. Meat Sci. 2010, 72, 9-17. [CrossRef] 
6. Tomovic, V.M.; Petrovic, L.S.; Dzinic, N.R. Effects of rapid chilling of carcasses and time of deboning on weight loss and technological quality of pork semimembranosus muscle. Meat Sci. 2008, 80, 1188-1193. [CrossRef]

7. Bertram, H.C.; Donstrup, S.; Karlsson, A.H.; Andersen, H.J.; Stodkilde-Jorgensen, H. Post mortem energy metabolism and pH development in porcine M-longissimus dorsi as affected by two different cooling regimes. A P-31-NMR spectroscopic study. Magn. Reson. Imaging 2001, 19, 993-1000. [CrossRef]

8. Holmer, S.F.; McKeith, F.K.; Killefer, J. The influence of early post-mortem enhancement and accelerated chilling on pork quality. Meat Sci. 2008, 79, 211-216. [CrossRef]

9. Sikes, A.L.; Jacob, R.; D'Arcy, B.; Warner, R. Very fast chilling modifies the structure of muscle fibres in hot-boned beef loin. Food Res. Int. 2017, 93, 75-86. [CrossRef]

10. Kim, Y.H.B.; Ma, D.; Setyabrata, D.; Farouk, M.M.; Lonergan, S.M.; Huff-Lonergan, E.; Hunt, M.C. Understanding postmortem biochemical processes and post-harvest aging factors to develop novel smart-aging strategies. Meat Sci. 2018, 144, 74-90. [CrossRef]

11. Long, V.P.; Tarrant, P.V. The effect of pre-slaughter showering and post-slaughter rapid chilling on meat quality in intact pork sides. Meat Sci. 1990, 27, 181-195. [CrossRef]

12. Kondjoyan, A.; Daudin, J.D. Optimisation of air-flow conditions during the chilling and storage of carcasses and meat products. J. Food Eng. 1997, 34, 243-258. [CrossRef]

13. AUS-MEAT. International Red Meat Manual; AUS-MEAT Limited: Queensland, Australia, 2005; p. 110.

14. Wu, H.; Yue, T.; Xu, Z.; Zhang, C. Sensor array optimization and discrimination of apple juices according to variety by an electronic nose. Anal. Methods 2017, 9, 921-928. [CrossRef]

15. Liu, H.; Ma, J.; Pan, T.; Suleman, R.; Wang, Z.; Zhang, D. Effects of roasting by charcoal, electric, microwave and superheated steam methods on volatile and non-volatile compounds in oyster cuts of roasted lamb. Meat Sci. 2021, 172, 108324. [CrossRef]

16. Liu, H.; Wang, Z.; Zhang, D.; Shen, Q.; Pan, T.; Hui, T.; Ma, J. Characterization of Key Aroma Compounds in Beijing Roasted Duck by Gas Chromatography-Olfactometry-Mass Spectrometry, Odor-Activity Values, and Aroma-Recombination Experiments. J. Agric. Food Chem. 2019, 67, 5847-5856. [CrossRef]

17. Fan, M.; Xiao, Q.; Xie, J.; Cheng, J.; Sun, B.; Du, W.; Wang, Y.; Wang, T. Aroma Compounds in Chicken Broths of Beijing Youji and Commercial Broilers. J. Agric. Food Chem. 2018, 66, 10242-10251. [CrossRef]

18. Zhang, Z.; Elfalleh, W.; He, S.; Tang, M.; Zhao, J.; Wu, Z.; Wang, J.; Sun, H. Heating and cysteine effect on physicochemical and flavor properties of soybean peptide Maillard reaction products. Int. J. Biol. Macromol. 2018, 120, 2137-2146. [CrossRef]

19. Zou, Y.; Kang, D.; Liu, R.; Qi, J.; Zhou, G.; Zhang, W. Effects of ultrasonic assisted cooking on the chemical profiles of taste and flavor of spiced beef. Ultrason. Sonochemistry 2018, 46, 36-45. [CrossRef]

20. Offer, G. Modelling of the formation of pale, soft and exudative meat: Effects of chilling regime and rate and extent of glycolysis. Meat Sci. 1991, 30, 157-184. [CrossRef]

21. Rathgeber, B.M.; Pato, M.D.; Boles, J.A.; Shand, P.J. Rapid post-mortem glycolysis and delay chilling of turkey carcasses cause alterations to protein extractability and degradation of breast muscle proteins. J. Agric. Food Chem. 1999, 47, 2529-2536. [CrossRef] [PubMed]

22. Kyla-Puhju, M.; Ruusunen, M.; Puolanne, E. Activity of porcine muscle glycogen debranching enzyme in relation to pH and temperature. Meat Sci. 2005, 69, 143-149. [CrossRef]

23. Matarneh, S.K.; Yen, C.N.; Bodmer, J.; El-Kadi, S.W.; Gerrard, D.E. Mitochondria influence glycolytic and tricarboxylic acid cycle metabolism under postmortem simulating conditions. Meat Sci. 2021, 172, 108316. [CrossRef] [PubMed]

24. Frylinck, L.; Strydom, P.E.; Webb, E.C.; du Toit, E. Effect of South African beef production systems on post-mortem muscle energy status and meat quality. Meat Sci. 2013, 93, 827-837. [CrossRef]

25. Straadt, I.K.; Aaslyng, M.D.; Bertram, H.C. An NMR-based metabolomics study of pork from different crossbreeds and relation to sensory perception. Meat Sci. 2014, 96, 719-728. [CrossRef] [PubMed]

26. Wood, J.D.; Enser, M.; Fisher, A.V.; Nute, G.R.; Richardson, R.I.; Sheard, P.R. Manipulating meat quality and composition. Proc. Nutr. Soc. 1999, 58, 363-370. [CrossRef]

27. Baron, C.P.; Kjaersgard, I.V.; Jessen, F.; Jacobsen, C. Protein and lipid oxidation during frozen storage of rainbow trout (Oncorhynchus mykiss). J. Agric. Food Chem. 2007, 55, 8118-8125. [CrossRef] [PubMed]

28. Wang, Z.; Tu, J.; Zhou, H.; Lu, A.; Xu, B. A comprehensive insight into the effects of microbial spoilage, myoglobin autoxidation, lipid oxidation, and protein oxidation on the discoloration of rabbit meat during retail display. Meat Sci. 2021, 172, 108359. [CrossRef]

29. Li, X.; Zhu, J.; Qi, J.; Wang, P.; Xu, X.; Zhou, G. Superchilled storage $\left(-2.5 \pm 1{ }^{\circ} \mathrm{C}\right)$ extends the retention of taste-active and volatile compounds of yellow-feather chicken soup. Anim. Sci. J. 2018, 89, 906-918. [CrossRef] [PubMed]

30. Yu, D.; Wu, L.; Regenstein, J.M.; Jiang, Q.; Yang, F.; Xu, Y.; Xia, W. Recent advances in quality retention of non-frozen fish and fishery products: A review. Crit. Rev. Food Sci. Nutr. 2020, 60, 1747-1759. [CrossRef]

31. Mohrhauser, D.A.; Lonergan, S.M.; Huff-Lonergan, E.; Underwood, K.R.; Weaver, A.D. Calpain-1 activity in bovine muscle is primarily influenced by temperature, not $\mathrm{pH}$ decline. J. Anim. Sci. 2014, 92, 1261-1270. [CrossRef]

32. Watanabe, A.; Kamada, G.; Imanari, M.; Shiba, N.; Yonai, M.; Muramoto, T. Effect of aging on volatile compounds in cooked beef. Meat Sci. 2015, 107, 12-19. [CrossRef] [PubMed]

33. Imafidon, G.I.; Spanier, A.M. Unraveling the secret of meat flavor. Trends Food Sci. Technol. 1994, 5, 315-321. [CrossRef] 
34. Wang, F.; Gao, Y.; Wang, H.; Xi, B.; He, X.; Yang, X.; Li, W. Analysis of volatile compounds and flavor fingerprint in Jingyuan lamb of different ages using gas chromatography-ion mobility spectrometry (GC-IMS). Meat Sci. 2021, 175, 108449. [CrossRef]

35. Insausti, K.; Murillo-Arbizu, M.T.; Urrutia, O.; Mendizabal, J.A.; Beriain, M.J.; Colle, M.J.; Bass, P.D.; Arana, A. Volatile Compounds, Odour and Flavour Attributes of Lamb Meat from the Navarra Breed as Affected by Ageing. Foods 2021, 10, 493. [CrossRef]

36. Shahidi, F.; Rubin, L.J.; D'Souza, L.A. Meat flavor volatiles: A review of the composition, techniques of analysis, and sensory evaluation. Crit. Rev. Food Sci. Nutr. 1986, 24, 141-243. [CrossRef] [PubMed]

37. Karabagias, I. Volatile Profile of Raw Lamb Meat Stored at $4 \pm 1{ }^{\circ} \mathrm{C}$ : The Potential of Specific Aldehyde Ratios as Indicators of Lamb Meat Quality. Foods 2018, 7, 40. [CrossRef]

38. Girard, B.; Durance, T. Headspace volatiles of sockeye and pink salmon as affected by retort process. J. Food Sci. 2000, 65, 34-39. [CrossRef]

39. Chen, W.; Li, W.; Yang, Y.; Yu, H.; Zhou, S.; Feng, J.; Li, X.; Liu, Y. Analysis and evaluation of tasty components in the pileus and stipe of Lentinula edodes at different growth stages. J. Agric. Food Chem. 2015, 63, 795-801. [CrossRef] [PubMed]

40. Yamaguchi, S. Fundamental properties of umami taste. J. Agric. Chem. Soc. Jpn. 1991, 65, 903-906.

41. Sabikun, N.; Bakhsh, A.; Rahman, M.S.; Hwang, Y.H.; Joo, S.T. Volatile and nonvolatile taste compounds and their correlation with umami and flavor characteristics of chicken nuggets added with milkfat and potato mash. Food Chem. 2020, 343, 128499. [CrossRef]

42. Yamaguchi, S.; Yoshikawa, T.; Ikeda, S.; Ninomiya, T. Measurement of the relative taste intensity of some L- $\alpha$-amino acids and 5'-nucleotides. J. Food Sci. 1971, 36, 846-849. [CrossRef]

43. Zhang, L.; Yin, M.; Zheng, Y.; Xu, C.H.; Tao, N.P.; Wu, X.; Wang, X. Brackish water improves the taste quality in meat of adult male Eriocheir sinensis during the postharvest temporary rearing. Food Chem. 2021, 343, 128409. [CrossRef]

44. Liu, C.; Ji, W.; Jiang, H.; Shi, Y.; He, L.; Gu, Z.; Zhu, S. Comparison of biochemical composition and non-volatile taste active compounds in raw, high hydrostatic pressure-treated and steamed oysters Crassostrea hongkongensis. Food Chem. 2020, 342, 128632. [CrossRef]

45. Wang, Z.; He, Z.; Gan, X.; Li, H. Interrelationship among ferrous myoglobin, lipid and protein oxidations in rabbit meat during refrigerated and superchilled storage. Meat Sci. 2018, 146, 131-139. [CrossRef] [PubMed]

46. Han, G.; Zhang, L.; Li, Q.; Wang, Y.; Chen, Q.; Kong, B. Impacts of different altitudes and natural drying times on lipolysis, lipid oxidation and flavour profile of traditional Tibetan yak jerky. Meat Sci. 2020, 162, 108030. [CrossRef]

47. Minami, S.; Sato, M.; Shiraiwa, Y.; Iwamoto, K. Molecular characterization of adenosine 5'-monophosphate deaminase-the key enzyme responsible for the umami taste of nori (Porphyra yezoensis Ueda, Rhodophyta). Mar. Biotechnol. 2011, 13, 1140-1147. [CrossRef] [PubMed]

48. Jolley, P.D.; Honikel, K.O.; Hamm, R. Influence of temperature on the rate of post-mortem metabolism and water-holding capacity of bovine neck muscles. Meat Sci. 1981, 5, 99-107. [CrossRef]

49. Stetzer, A.J.; Cadwallader, K.; Singh, T.K.; McKeith, F.K.; Brewer, M.S. Effect of enhancement and ageing on flavor and volatile compounds in various beef muscles. Meat Sci. 2008, 79, 13-19. [CrossRef]

50. Tikk, M.; Tikk, K.; Torngren, M.A.; Meinert, L.; Aaslyng, M.D.; Karlsson, A.H.; Andersen, H.J. Development of inosine monophosphate and its degradation products during aging of pork of different qualities in relation to basic taste and retronasal flavor perception of the meat. J. Agric. Food Chem. 2006, 54, 7769-7777. [CrossRef]

51. Li, J.; Tang, C.; Zhao, Q.; Yang, Y.; Li, F.; Qin, Y.; Liu, X.; Yue, X.; Zhang, J. Integrated lipidomics and targeted metabolomics analyses reveal changes in flavor precursors in psoas major muscle of castrated lambs. Food Chem. 2020, 333, 127451. [CrossRef]

52. Honikel, K.O.; Hamm, R. Influence of cooling and freezing of minced pre-rigor muscle on the breakdown of ATP and glycogen. Meat Sci. 1978, 2, 181-188. [CrossRef]

53. Benet, I.; Guardia, M.D.; Ibanez, C.; Sola, J.; Arnau, J.; Roura, E. Low intramuscular fat (but high in PUFA) content in cooked cured pork ham decreased Maillard reaction volatiles and pleasing aroma attributes. Food Chem. 2016, 196, 76-82. [CrossRef] [PubMed]

54. Williamson, J.; Ryland, D.; Suh, M.; Aliani, M. The effect of chilled conditioning at $4{ }^{\circ} \mathrm{C}$ on selected water and lipid-soluble flavor precursors in Bison bison longissimus dorsi muscle and their impact on sensory characteristics. Meat Sci. 2014, 96, 136-146. [CrossRef]

55. Resconi, V.C.; Bueno, M.; Escudero, A.; Magalhaes, D.; Ferreira, V.; Campo, M.M. Ageing and retail display time in raw beef odour according to the degree of lipid oxidation. Food Chem. 2018, 242, 288-300. [CrossRef] [PubMed]

56. Van Ba, H.; Amna, T.; Hwang, I. Significant influence of particular unsaturated fatty acids and $\mathrm{pH}$ on the volatile compounds in meat-like model systems. Meat Sci. 2013, 94, 480-488. [CrossRef]

57. Kosowska, M.; Majcher, M.A.; Fortuna, T. Volatile compounds in meat and meat products. Food Sci. Technol. 2017, 37, 1-7. [CrossRef]

58. Du, M.; Li, X.; Li, Z.; Shen, Q.; Wang, Y.; Li, G.; Zhang, D. Effects of phosphorylation on mu-calpain activity at different incubation temperature. Food Res. Int. 2017, 100, 318-324. [CrossRef]

59. Ren, C.; Hou, C.; Li, Z.; Li, X.; Bai, Y.; Zhang, D. Effects of temperature on protein phosphorylation in postmortem muscle. J. Sci. Food Agric. 2020, 100, 551-559. [CrossRef] [PubMed]

60. Koohmaraie, M.; Whipple, G.; Kretchmar, D.H.; Crouse, J.D.; Mersmann, H.J. Postmortem proteolysis in longissimus muscle from beef, lamb and pork carcasses. J. Anim. Sci. 1991, 69, 617-624. [CrossRef] 
61. Sinz, Q.; Schwab, W. Metabolism of amino acids, dipeptides and tetrapeptides by Lactobacillus sakei. Food Microbiol. 2012, 29, 215-223. [CrossRef]

62. Chen, L.; Bai, Y.; Everaert, N.; Li, X.; Tian, G.; Hou, C.; Zhang, D. Effects of protein phosphorylation on glycolysis through the regulation of enzyme activity in ovine muscle. Food Chem. 2019, 293, 537-544. [CrossRef] [PubMed] 